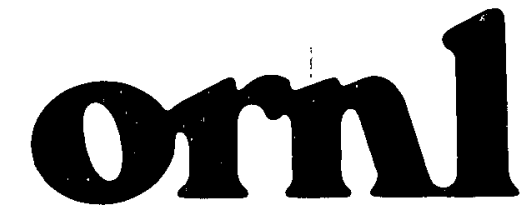

OAK RIDGE NATIONAL

MARTIN MARIETTA LABORATORY

\section{The Development of a Preliminary Correlation of Data on Oxide Growth on 6061 Aluminum Under ANS Thermal-Hydraulic Conditions}

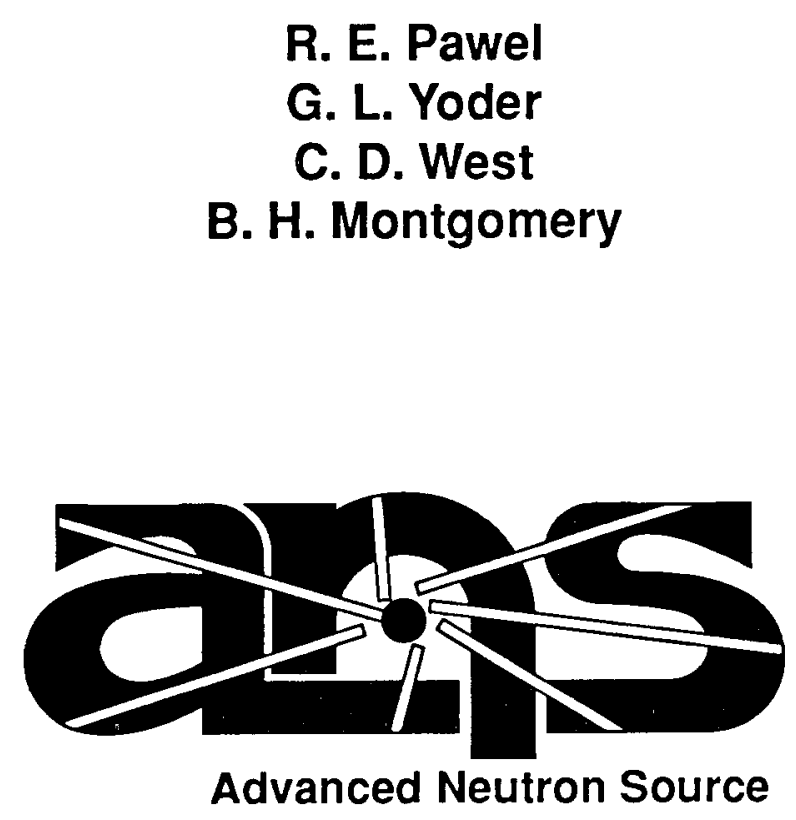

R. E. Pawel

G. L. Yoder

C. D. West

B. H. Montgomery

MANAGED BY

MARTIN MARIETTA ENERGY SYSTEMS, INC.

FOR THE UNITED STATES

DEPARTMENT OF ENERGY 
This report has been reproduced directly from the best available copy.

Available to DOE and DOE contractors from the Office of Scientific and Technical Information, P.O. Box 62, Oak Ridge, TN 37831; prices available from (615) 576-8401, FTS 626-8401.

Available to the public from the National Technical Information Service, U.S. Department of Commerce, 5285 Port Royal Rd., Springfield, VA 22161.

NTIS price codes-Printed Copy: $\mathrm{AO} 4$ Microfiche AO1

This report was prepared as an account of work sponsored by an agency of the United States Government. Neither the United States Government nor any agency thereof, nor any of their employees, makes any warranty, express or implied, or assumes any legal liability or responsibility for the accuracy, completeness, or usefulness of any information, apparatus, product, or process disclosed, or represents that its use would not infringe privately owned rights. Reference herein to any specific commercial product, process, or service by trade name, trademark, manufacturer, or otherwise, does not necessarily constitute or imply its endorsement, recommendation, or favoring by the United States Government or any agency thereof. The views and opinions of authors expressed herein do not necessarily state or reflect those of the United States Government or any agency thereof. 


\section{DISCLAIMER}

This report was prepared as an account of work sponsored by an agency of the United States Government. Neither the United States Government nor any agency Thereof, nor any of their employees, makes any warranty, express or implied, or assumes any legal liability or responsibility for the accuracy, completeness, or usefulness of any information, apparatus, product, or process disclosed, or represents that its use would not infringe privately owned rights. Reference herein to any specific commercial product, process, or service by trade name, trademark, manufacturer, or otherwise does not necessarily constitute or imply its endorsement, recommendation, or favoring by the United States Government or any agency thereof. The views and opinions of authors expressed herein do not necessarily state or reflect those of the United States Government or any agency thereof. 


\section{DISCLAIMER}

Portions of this document may be illegible in electronic image products. Images are produced from the best available original document. 


\title{
THE DEVELOPMENT OF A PRELIMINARY CORRELATION OF DATA ON OXIDE GROWTH ON 6061 ALUMINUM UNDER ANS THERMAL-HYDRAULIC CONDITIONS
}

\author{
R. E. Pawel \\ G. L. Yoder \\ C. D. West
}

B. H. Montgomery

June 1990

\author{
Prepared for \\ Office of Technology Application
}

DOE Budget Activity Number KC 0204010

Prepared by the

OAK RIDGE NATIONAL LABORATORY

Oak Ridge, Tennessee 37831

operated by

MARTIN MARIETTA ENERGY SYSTEMS, INC.

for the

U.S. DEPARTMENT OF ENERGY under contract DE-AC05-84OR21400

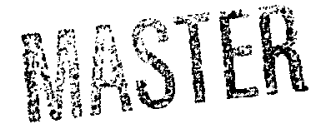


LIST OF FIGURES $\ldots \ldots \ldots \ldots \ldots \ldots \ldots \ldots \ldots \ldots \ldots \ldots \ldots \ldots \ldots \ldots \ldots$

LIST OF TABLES $\ldots \ldots \ldots \ldots \ldots \ldots \ldots \ldots \ldots \ldots \ldots \ldots \ldots \ldots \ldots \ldots \ldots \ldots$

NOMENCLATURE $\ldots \ldots \ldots \ldots \ldots \ldots \ldots \ldots \ldots \ldots \ldots \ldots \ldots \ldots \ldots$ vi

ACRONYMS $\ldots \ldots \ldots \ldots \ldots \ldots \ldots \ldots \ldots \ldots \ldots \ldots \ldots \ldots \ldots \ldots \ldots \ldots \ldots \ldots \ldots$

ABSTRACT $\ldots \ldots \ldots \ldots \ldots \ldots \ldots \ldots \ldots \ldots \ldots \ldots \ldots \ldots \ldots \ldots \ldots \ldots \ldots \ldots \ldots$

1. INTRODUCTION $\ldots \ldots \ldots \ldots \ldots \ldots \ldots \ldots \ldots \ldots \ldots \ldots \ldots \ldots \ldots \ldots \ldots \ldots \ldots \ldots$

2. QUALITATIVE OBSERVATIONS $\ldots \ldots \ldots \ldots \ldots \ldots \ldots \ldots \ldots \ldots \ldots \ldots$

3. CORRELATION PROCEDURES $\ldots \ldots \ldots \ldots \ldots \ldots \ldots \ldots \ldots \ldots \ldots \ldots \ldots \ldots \ldots \ldots$

4. ASSIGNMENT OF DATA BASE $\ldots \ldots \ldots \ldots \ldots \ldots \ldots \ldots \ldots \ldots \ldots \ldots \ldots \ldots \ldots \ldots$

5. BASIC EMPIRICAL APPROACH $\ldots \ldots \ldots \ldots \ldots \ldots \ldots \ldots \ldots \ldots \ldots \ldots \ldots \ldots$

6. RATE FUNCTIONS $\ldots \ldots \ldots \ldots \ldots \ldots \ldots \ldots \ldots \ldots \ldots \ldots \ldots \ldots \ldots \ldots$

7. RESULTS $[\mathrm{METHOD}(\mathrm{A})] \ldots \ldots \ldots \ldots \ldots \ldots \ldots \ldots \ldots \ldots \ldots \ldots \ldots \ldots \ldots \ldots \ldots$

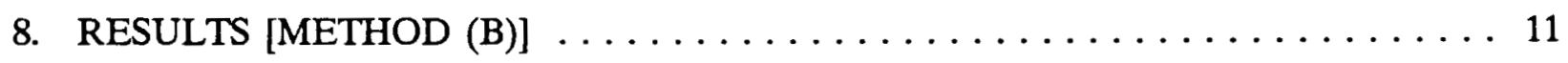

9. RESULTS [SPALLATION CRITERION] $\ldots \ldots \ldots \ldots \ldots \ldots \ldots \ldots \ldots \ldots$

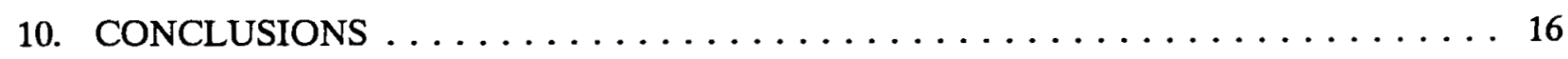

ACKNOWLEDGMENTS $\ldots \ldots \ldots \ldots \ldots \ldots \ldots \ldots \ldots \ldots \ldots \ldots \ldots \ldots \ldots \ldots \ldots$

REFERENCES $\ldots \ldots \ldots \ldots \ldots \ldots \ldots \ldots \ldots \ldots \ldots \ldots \ldots \ldots \ldots \ldots \ldots \ldots \ldots \ldots \ldots$ 


\section{LIST OF FIGURES}

Figure

Page

1 Photograph of ANS corrosion loop test facility $\ldots \ldots \ldots \ldots \ldots \ldots$

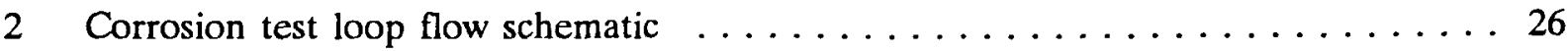

3 Thickness-vs-time results at different coolant $\mathrm{pH} \ldots \ldots \ldots \ldots \ldots \ldots$

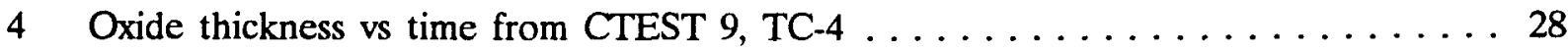

5 Electron microprobe scan showing thin layer of iron-rich material on outer surface of film . . . . . . . . . . . . . . . . . 29

6 Thickness-vs-time results for a pH 4.5 medium heat flux run $\ldots \ldots \ldots \ldots$

7 Thickness-vs-time results for two different inlet temperature values $\ldots \ldots \ldots 31$

8 Oxide growth rate vs bulk water temperature for CTEST $6 \ldots \ldots \ldots$

9 Initial growth rate vs bulk water temperature for varying

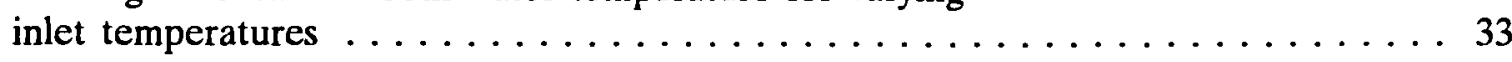

10 Cross section of spalled and unspalled regions of test specimen $\ldots \ldots \ldots \ldots$

11 Oxide growth curves from ANSDAT illustrating use of second-order polynomials to represent data $\ldots \ldots \ldots \ldots \ldots \ldots \ldots \ldots$

12 Measured-vs-predicted growth rates [via Eq. (6)]

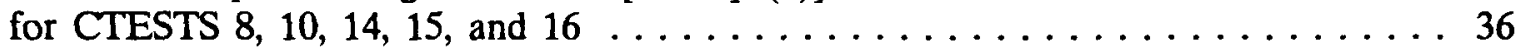

13 Arrhenius plot for rate constant $k$ and the rate parameter $\left(\mathrm{T}_{c}+10 \phi\right)$ showing the conservative estimator $\ldots \ldots \ldots \ldots \ldots$

14 Measured and predicted film thicknesses for CTEST $8 \ldots \ldots \ldots \ldots \ldots$

15 Measured and predicted film thicknesses for CTEST $10 \ldots \ldots \ldots \ldots$

16 Measured and predicted film thicknesses for CTEST $15 \ldots \ldots \ldots \ldots$

17 Measured and predicted film thicknesses for CTEST $16 \ldots \ldots \ldots \ldots \ldots \ldots$

18 Measured and predicted film thicknesses for CTEST 16,

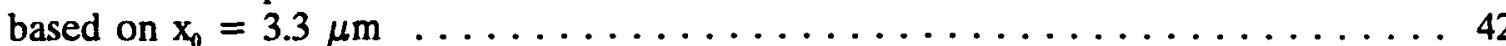


19 Measured and predicted film thicknesses for CTEST 9, a test conducted with $\mathrm{T}_{\mathrm{ci}}=57^{\circ} \mathrm{C}$, out of the range intended for preliminary correlation

20 Measured and predicted film thicknesses according to the

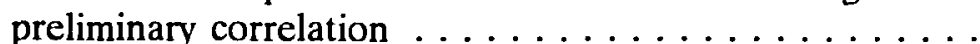

21 Metal-oxide interface temperatures at time of spallation

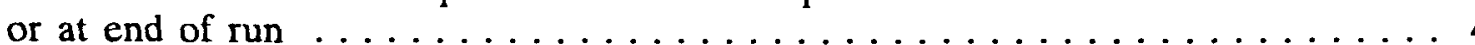

22 Temperature difference across the oxide at time of spallation

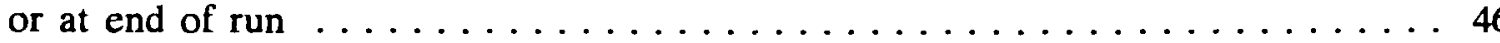




\section{LIST OF TABLES}

Table

Page

1 Corrosion test loop: completed tests and parameters $\ldots \ldots \ldots \ldots \ldots \ldots$

2 Evaluation of characteristic temperatures in Eq. (6) $\ldots \ldots \ldots \ldots \ldots$

$3 \quad$ Measured slopes of $\ln \mathrm{x}$ vs $\ln \mathrm{t}$ curves from $\mathrm{OXCAL} \ldots \ldots \ldots \ldots \ldots$

4 OXCAL-generated data set for rate correlation determinations $\ldots \ldots \ldots \ldots 22$

5 List of changes in metal-oxide interface temperatures at time of spalling or end of run for all CTESTs and their TCs . . . . . . . . . 23

6 List of oxide temperature differences at time of spalling or end of run for all CTESTs and their TCs . . . . . . . . . . . . . . . . 24 


\section{NOMENCLATURE}

k Rate constant for film growth, defined in Eq. (1)

n Mechanism constant for film growth, defined in Eq. (1)

Q Activation energy, defined in Eq. (4)

R Gas constant, $8.314 \mathrm{~J} / \mathrm{mol} \mathrm{K}$

$\mathrm{t} \quad$ Time, $\mathrm{h}$

$\mathrm{T} \quad$ Temperature, $\mathrm{K}$

$\mathrm{T}_{\mathrm{ci}} \quad$ Coolant inlet temperature, $\mathrm{K}$

$\mathrm{T}_{\infty} \quad$ Coolant outlet temperature, $\mathrm{K}$

$\mathrm{T}_{\mathrm{c}} \quad$ Coolant temperature, local, $\mathrm{K}$

$\mathrm{T}_{\mathrm{x} / \mathrm{c}} \quad$ Oxide-coolant interface temperature, $\mathrm{K}$

$T_{x} \quad$ Oxide temperature, average, local, $\mathrm{K}$

$T_{m / x} \quad$ Metal-oxide interface temperature, local, $\mathrm{K}$

$\mathrm{V}_{\mathrm{c}} \quad$ Coolant velocity, $\mathrm{m} / \mathrm{s}$

$\mathrm{x} \quad$ Oxide (boehmite) layer thickness, $\mu \mathrm{m}$

$\phi_{\text {avg }}$ Heat flux, average, $\mathrm{MW} / \mathrm{m}^{2}$

$\phi \quad$ Heat flux, local, $\mathrm{MW} / \mathrm{m}^{2}$ 


\section{vii}

\section{ACRONYMS}
ANS Advanced Neutron Source
ORNL Oak Ridge National Laboratory
HFIR High Flux Isotope Reactor
ATR Advanced Test Reactor
ANSDAT A computer program developed at ORNL to reduce the raw corrosion test data
OXCAL A computer program developed at ORNL to reduce the raw corrosion test data
CTEST Corrosion Loop Tests numbering system
SAS Statistical analysis computer software program 


\title{
THE DEVELOPMENT OF A PRELIMINARY CORRELATION \\ OF DATA ON OXIDE GROWTH ON 6061 ALUMINUM UNDER ANS THERMAL-HYDRAULIC CONDITIONS
}

\author{
R. E. Pawel \\ C. D. West \\ G. L. Yoder \\ B. H. Montgomery
}

\begin{abstract}
The corrosion of aluminum alloy 6061 is being studied in a special test loop facility under the range of thermal-hydraulic conditions appropriate for fuel plate operation in the Advanced Neutron Source (ANS) reactor core. Experimental measurements describing the growth of the boehmite $\left(\mathrm{Al}_{2} \mathrm{O}_{3} \mathrm{H}_{2} \mathrm{O}\right)$ films on the exposed aluminum surfaces are now available for a range of coolant conditions and heat fluxes, and these results have been analyzed to demonstrate the influence of several important experimental variables. A subset of our data base particularly appropriate to the ANS conditions presently anticipated was used to develop a preliminary correlation based on an empirical oxidation model. This analysis, based on tests with coolant inlet temperatures between 39 and $49^{\circ} \mathrm{C}$ and coolant velocities between 25 and $28 \mathrm{~m} / \mathrm{s}$, resulted in the following expression:

$$
\mathrm{dx} / \mathrm{dt}=\mathrm{k} / \mathrm{x}^{\mathrm{n}},
$$
\end{abstract}

where

$$
\begin{aligned}
\mathrm{dx} / \mathrm{dt} & =\text { rate of layer growth, } \mu \mathrm{m} / \mathrm{h} \\
\mathrm{x} & =\text { layer thickness, } \mu \mathrm{m} ; \\
\mathbf{n} & =\text { constant, } 0.351 ; \\
\mathbf{k} & \left.\left.=6.992 \mathrm{E} 5 \text { exp[-7592/( } \mathrm{T}_{\mathrm{c}}+10 \phi\right)\right] \mu \mathrm{m}^{1351} / \mathrm{h} ; \\
\mathrm{T}_{c} & =\text { local coolant temperature, } \mathrm{K} ; \\
\phi & =\text { local heat flux, } \mathrm{MW} / \mathrm{m}^{2}
\end{aligned}
$$

This expression will predict the oxide thickness (and thence temperature changes in the cladding and fuel) at given points of the clad surface as a function of their thermal-hydraulic history.

In addition, data analyses of all tests with a $\mathrm{pH}$ of $\sim 5$ and a heat flux of $\sim 11 \mathrm{MW} / \mathrm{m}^{2}$ shows that the growth rate increases rapidly with local coolant temperature in those tests where the inlet temperature was $57^{\circ} \mathrm{C}$ or higher and that for tests with inlet temperatures below $50^{\circ} \mathrm{C}$ the growth rate remains low even at higher local temperatures. From this observation, we have recommended that the reactor designers maintain the reactor primary inlet coolant at $<50^{\circ} \mathrm{C}$. Also, on the basis of our tests performed under approximately steady-state coolant and power conditions, we have proposed that spallation of the oxide film, an undesirable event for ANS fuel cladding, takes place only when the temperature at the oxide-metal interface has increased by more than $114^{\circ} \mathrm{C}$ or when the temperature drop across the oxide film exceeds $119^{\circ} \mathrm{C}$ (which is an almost equivalent condition).

Experimental efforts are continuing. It is expected that an expanded data base in conjunction with improved oxidation models and analysis will provide a more complete correlation for film growth as well as greater understanding of this complicated reaction. 


\section{INTRODUCTION}

Previous extensive experimental efforts at ORNL ${ }^{1,2}$ examined the corrosion behavior of several aluminum alloys in flowing $\mathrm{pH} 5$ to $\mathrm{pH} 7$ water under heat transfer conditions expected in the High Flux Isotope Reactor (HFIR). For heat fluxes from 3 to $6 \mathrm{MW} / \mathrm{m}^{2}$ and coolant flow rates from 10 to $15 \mathrm{~m} / \mathrm{s}$, the corrosion product, which was shown to be boehmite $\left(\mathrm{Al}_{2} \mathrm{O}_{3} \cdot \mathrm{H}_{2} \mathrm{O}\right)$, grew at a rate that was virtually independent of heat flux and coolant velocity. The oxide growth rate was proposed, in the famous "Griess Correlation," to be a function only of the boehmite-coolant interface temperature and the $\mathrm{pH}$ of the water. The assemblage of these data into the Griess Correlation has since been widely used to predict the extent of aluminum corrosion under various reactor conditions.

The limited range of variables addressed in the earlier work, although appropriate to the needs of the HFIR design team, required that supplementary experiments be performed under the more extreme thermal-hydraulic requirements of the Advanced Neutron Source (ANS) core. Consequently, we have paid particular attention to the possible effects (direct or indirect) of high heat flux and coolant velocity on the corrosion rate and have also investigated the influence of coolant $\mathrm{pH}$ and coolant temperature. So far, we have employed heat fluxes from about 5 to $20 \mathrm{MW} / \mathrm{m}^{2}$ and coolant velocities from 10 to $28 \mathrm{~m} / \mathrm{s}$ and have investigated the corrosion effects on 6061 aluminum alloy, the reference material for the ANS fuel cladding.

The basic objectives of the corrosion test program are (1) to ensure that excessive fuel and clad temperatures due to corrosion product buildup do not occur during the lifetime of the ANS core and (2) to ensure that the corrosion/erosion processes do not compromise the structural properties and containment capabilities of the fuel cladding. In order to utilize the evolving experimental information to meet these objectives, it is necessary to include a consideration of the influence of oxide film growth in the thermal-hydraulic aspects of the core design. A critical part of this procedure is the calculation of the layer thickness at any point on the fuel cladding as a function of its thermal-hydraulic history. An efficient technique to this end is to develop a viable oxidation "model" and to express the rate factor(s) as an analytical function of the operating system parameters, that is, to devise a new correlation, valid over the range of interest to the ANS design team, between the oxide growth and the operating conditions.

At this stage, all our experiments have been performed out-of-pile in the corrosion test loop, a specially built, high-pressure heated loop (Figs. 1 and 2) with light water. In-pile tests at the HFIR and out-of-pile tests with heavy water are planned for later in the program. 


\section{QUALITATIVE OBSERVATIONS}

The oxide growth rate in particular conditions of heat flux, $\mathrm{pH}$, inlet temperature, and flow

rate is approximately time independent, as indicated by Fig. 3, which shows thickness vs heat flux times time results for two different test conditions. For each set of conditions, the increase is approximately linear over the range covered. The implication is that the growth rate, at least over this range of conditions, is almost independent of the instantaneous oxide thickness, which for a wholly isothermal test would suggest that diffusion through the oxide layer is not a ratelimiting step; however, since the average temperature of the oxide increases with time, diffusioncontrolled growth is more complicated. In Fig. 4, where the conditions were restricted to measurements from one particular run, and at one particular thermocouple location, we see that the growth rate is really only approximately constant, tending to decrease with time. It should be noted that, on the graphs, the thickness means the thickness deduced from the measured temperature rise at the thermocouples attached to the aluminum test specimen.

Figure 3 also shows that the oxide growth rate is very dependent on the coolant water $\mathrm{pH}$. The data sets plotted in this figure were taken under approximately the same conditions of heat flux, inlet temperature, and flow rate, but with two different values of $\mathrm{pH}$.

Analysis shows that a very thin iron-rich layer appears on the surface under some conditions and is usually associated with very low oxide growth rates. Figure 5, an electron microprobe scan of one such layer, indicates that the iron appears at the oxide/water interface and not throughout the film. In conjunction with the results noted in the first paragraph of this section, this may imply that events at the water interface, not at the aluminum/oxide one, are limiting. Of course, the fact that iron and very low growth rates appear together does not prove, although it suggests, that the iron is responsible for the inhibition; the iron and the low growth might both be consequences of a single, so far unknown, cause.

Figure 6 shows that the oxide growth rate varies with position along the specimen for a given set of loop control parameters. In this figure, thickness vs time is plotted for a $\mathrm{pH} 4.5$, medium heat flux run. For a fixed inlet temperature, heat flux, and coolant velocity, the local coolant temperature (i.e., the average temperature of the water across the coolant channel gap at the point of measurement) increases along the length of the test specimen as do the interface temperature, heat flux, and oxide temperature. When the data points from different thermocouple positions (i.e., different bulk temperature) are identified, clearly separated growth 
rate curves appear. In fact, these differences among different thermocouple positions account for much of the scatter seen in Fig. 3. In Fig. 7 plots of oxide thickness at a single thermocouple position (TC-4) for each test are shown and the scatter is visibly less than that in Fig. 3.

Since the growth rate is approximately independent of instantaneous thickness under the conditions reported here (see above), a measure of growth rate is given by the slope of a straight line drawn through the thickness vs heat flux times time points. The results of such a calculation on the CTEST 6 data leads to Fig. 8 which adds further weight to the evidence for a strong growth rate/temperature correlation. In Fig. 8, the slope of the straight lines in Fig. 6 is plotted against local coolant or bulk water temperature. The slope in Fig. 8 indicates a doubling of growth rate for a temperature increase from $84^{\circ} \mathrm{C}$ to $101^{\circ} \mathrm{C}$. It should be noted that in this, as in some other plots, the cumulative product of heat flux and elapsed time was used in place of time as one variable to provide some compensation for the slight variations on heat flux imposed by the loop's automatic control system.

At a given $\mathrm{pH}$ and heat flux, the inlet water temperature has a strong influence on the growth rate observed at a particular thermocouple position, as indicated by Fig. 7, which plots the oxide thickness at thermocouple (TC) 4 vs time for the same $\mathrm{pH}$ and heat flux but different inlet temperatures and coolant velocities. The inlet temperature affects the local bulk temperature in direct proportion; so Fig. 7 does not, of itself, prove that inlet temperature has an effect separate from that of local temperature. However, in Fig. 9, there is further evidence that the growth rate also depends upon the inlet temperature; the results appear to fall into two groups, according to whether the inlet temperature is low $\left(39^{\circ} \mathrm{C}\right.$ to $\left.50^{\circ} \mathrm{C}\right)$ or high $\left(57^{\circ} \mathrm{C}\right.$ to $\left.80^{\circ} \mathrm{C}\right)$.

\section{CORRELATION PROCEDURES}

Although it is not appropriate or practical to define a sophisticated oxidation model and data correlation based on the present data or a first-principles analysis, an empirical treatment that reasonably describes the oxide film growth data would be a valuable product for predictive purposes. The nature of the empirical approach is clearly somewhat subjective, and several efforts by those involved are still in progress. One form of an acceptable correlation is presented here for present use by the reactor designers. Improved versions will be prepared, documented, and issued as the experimental and analytical work continues.

In addition to film growth rates, it is important to have a predictive capability for the onset of spallation or sloughing of the film since this is followed by severe degradation of the metal 
beneath the remnants of the spalled film (Fig. 10). The depth of the reaction zone can be large; therefore, spallation is considered unacceptable for ANS fuel cladding. A preliminary estimator for the initiation of spallation is also presented.

The details of the computational schemes employed to reduce the raw corrosion loop data will not be discussed here. Simply, two quite different computer programs (OXCAL and ANSDAT), developed completely independently, give very good agreement in calculating rate or growth curves; and we have tended to use these sets of results interchangeably. For data analyses, the ANSDAT results have been used chiefly to examine the instantaneous layer growth rates, $\mathrm{dx} / \mathrm{dt}$, in terms of several oxidation models, particularly those that account explicitly for the temperature increases of the oxide film during an experiment. The OXCAL results have so far been utilized to investigate empirical models that account for the increases in film temperature only implicitly.

\section{ASSIGNMENT OF DATA BASE}

Of the 16 corrosion loop tests (CTESTs) conducted so far, we have chosen a basis set of 11 that have the following features and parameter ranges (a subset of this basis set was chosen to formulate the preliminary data correlation advanced in this report):

Material: $6061 \mathrm{Al}$ (initially T6 temper).

Coolant pH: 5.0 (generally \pm 0.1 with isolated exceptions).

Coolant velocity, $\mathrm{V}_{\mathrm{c}}: 12.8$ to $28.0 \mathrm{~m} / \mathrm{s}$.

Coolant inlet temperature, $\mathrm{T}_{\mathrm{c}}: 39$ to $80^{\circ} \mathrm{C}$.

Local coolant temperature, $T_{c}: 44$ to $99^{\circ} \mathrm{C}$.

Local interface temperature, $\mathrm{T}_{\mathrm{x} / \mathrm{c}}: 95$ to $201^{\circ} \mathrm{C}$.

Local heat flux, $\phi: 5.2$ to $20.2 \mathrm{MW} / \mathrm{m}^{2}$.

Details are given in Table 1. CTESTs 1 and 2 are excluded because they were not conducted as data-gathering experiments but as part of the loop conditioning when loop parameters were unstable.

The ANSDAT program considers the film growth at five active thermocouple positions (TCs 2-6) equidistant along the specimen length for each experiment. The OXCAL program considers only three positions (TCs 2,4 , and 6 ), the ones for which separate measurements are 
available on both sides of the specimen (TCs 8, 9, and 10). For purposes of this data base, we consider the film growth at each position to be a "separate experiment" or "data set" since different conditions always exist (i.e., there are axial temperature gradients). An important consequence of the axial temperature gradient in the metal is that the heat flux is greater at the hot end (outlet) than at the cooler end (inlet) because of the temperature dependence of aluminum's electrical conductivity. Because the reaction products thicken more rapidly at the hotter end, the extent of the variation in heat flux over the specimen increases during an experiment. Only at a position near the axial midpoint will the heat flux remain essentially unchanged throughout the test. While this effect will, in principle, influence the accuracy of certain of the empirical models based on the use of "average" parameter values in describing many of the data sets, we have assumed that the effect is small. (The ANSDAT data for instantaneous growth rates do not require this approximation.)

In addition, in both OXCAL and ANSDAT, the film thicknesses are derived from calculations of the temperature drop across the film, assuming a thermal conductivity of 2.25 $\mathrm{W} / \mathrm{m} \cdot \mathrm{K}$ While we will eventually calculate an experimental value of the thermal conductivity of the product film based on our measurements, the present value appears to be quite accurate, and no meaningful loss in accuracy of subsequently calculated temperatures and changes in temperature would result from a different conductivity value, provided consistent values are used in interpreting the results as in applying them.

\section{BASIC EMPIRICAL APPROACH}

From our data sets, it has been observed with few exceptions that the thickness of the product film at a given point on the specimen increases at a slightly decreasing rate (e.g., see Fig. 11). While it was apparent that ideal "parabolic" growth was not occurring, perhaps because of increasing temperatures in the oxide film, the curves generally appeared consistent with a typical rate equation:

$$
\mathrm{dx} / \mathrm{dt}=\mathrm{k} / \mathrm{x}^{\mathrm{n}}
$$

where

$$
\begin{aligned}
& \mathbf{x}=\text { film thickness, } \mu \mathrm{m} ; \\
& \mathbf{t}=\text { time, } \mathrm{h} ; \\
& \mathbf{k}=\text { rate constant, } \mu \mathrm{m}^{\mathrm{n}+1} / \mathrm{h} ; \\
& \mathbf{n}=\text { constant ("mechanism number"). }
\end{aligned}
$$


The fact that many oxidation systems seem to follow this simple rate equation explains its popularity, and the kinetic result of complicated changes in diffusion behavior in a growing film can often be accounted for empirically by noting that $n$ is not equal to 1 and/or is time dependent. In addition, the influence of changing film temperatures as in the present experiments can be practically accounted for in this manner. The Griess Correlation invoked a growth equation of this form.

If Eq. (1) applies, then a correlation of the data may be achieved by determining the best values of the parameters $\mathrm{k}$ and $\mathrm{n}$ as a function of the system conditions (temperature, heat flux, coolant velocities, etc.). This can be accomplished by (A) working directly with "rate data" (a direct output of the ANSDAT program) as in Eq. (1) or (B) working with some form of the integrated equation assuming that neither parameter is explicitly time dependent (using output data from either ANSDAT or OXCAL). The integrated equation takes the form

$$
x_{t}=\left[x_{o}^{n+1}+(n+1) k t\right]^{1 /(n+1)} \text {, }
$$

where $x_{1}$ is the film thickness at time $t(\mu \mathrm{m})$ and $x_{0}$ is the film thickness at $t=0(\mu \mathrm{m})$. Both approaches are being followed. Method $(\mathrm{A})$ is relatively straightforward but requires assumptions for the form of the dependencies of the factors $k$ and $n$ on the experimental variables. Method (B) requires similar assumptions but may be less sensitive to the particular manner in which the data are smoothed because $\mathrm{n}$ and $\mathrm{k}$ are determined separately. For Method (B) to be most useful, $n$ should be representative of all data sets or at least that group of data sets that were taken under reactor-like conditions.

Method (A), the more sophisticated approach, is in progress, but results are incomplete at the time of writing this report. The approach taken here is to perform a statistical analysis of the ANSDAT data for the 11 CTESTs and, separately, certain subsets thereof (using the SAS program) on a model derived from Eq. (1).

$$
\ln (\mathrm{dx} / \mathrm{dt})=\ln \mathrm{k}-\mathrm{n} \ln \mathrm{x},
$$

where $\mathbf{k}$ is considered to be a function of several specified system parameters as well as the continuously changing film temperature. The value of $\mathbf{n}$ can be determined by a least-squares analysis, or else it can have a preassigned value. For the case of ideal, diffusion-controlled layer growth, $\mathbf{n}$ would be equal to unity (the parabolic growth law), while $\mathbf{k}$ would be directly related to a chemical diffusion coefficient and thus would vary exponentially with the mean film temperature according to an Arrhenius equation. 
Method (B) has been used to produce the first preliminary correlations. In this instance, the OXCAL outputs for film thickness as a function of time for the 11 tests times three thermocouple positions (i.e., 33 data elements) included in the data base were involved.' Subsets based on tests having common coolant inlet temperatures, similar to those expected in the ANS reactor, were also examined. Note that our experimental results show, we believe for the first time, that the inlet temperature is an independent variable, influencing the oxide growth rate directly as well as through its influence on coolant temperature in the test section. The steps in the analysis were as follows:

B1. Determine if a single value of $\mathrm{n}$ in Eq. (2) was a suitable approximation for use with the entire data set; if so, then

B2. determine $\mathrm{k}$ in Eq. (2) for each of the experiments of the data set; and finally

B3. find an empirical correlation between $\mathrm{k}$ and the system parameters (temperatures, etc.) that conservatively describes all the data.

With a conservative correlation, the reactor designers can feel secure that they are within a safe operating region.

\section{RATE FUNCTIONS}

As noted earlier, for isothermal oxidation experiments that tend to obey the simple rate equations previously discussed for $\mathbf{n} \neq 0$, some form of diffusion control is usually acting. Thus the rate constant will commonly be given by an Arrhenius expression of the form

$$
\mathbf{k}=\mathrm{A} \exp (-\mathrm{Q} / \mathrm{RT})
$$

where

$$
\begin{aligned}
& \mathbf{k}=\text { oxidation rate constant; } \\
& \mathrm{A}=\text { constant, appropriate units; } \\
& \mathrm{Q}=\text { activation energy, } \mathrm{J} / \mathrm{mol} ; \\
& \mathrm{R}=\text { gas constant, } 8.314 \mathrm{~J} / \mathrm{mol} \cdot \mathrm{K} ; \\
& \mathrm{T}=\text { absolute temperature, } \mathrm{K}
\end{aligned}
$$

These data are available in hard copy (OXCAL outputs) in ANS files and in disk files associated with SIGMAPLOT graphics program. 
It is observed that the Griess Correlation involves a form for the rate constant identical to that of Eq. (4), ${ }^{3}$ with the decisive temperature being taken as the oxide-coolant interface temperature, $T_{x / c}$, regardless of the other experimental variables. In the present investigation, we have seen clear evidence that several other parameters affect the rate of film growth ${ }^{4}$ and that $\mathbf{k}$ also may be a function of these other parameters. A parallel approach would be to accept the Arrhenius form of the rate equation but to assume that $\mathrm{T}$ represents an "effective temperature" that is a function of other parameters.

Our experience with numerous comparisons of the observed growth rate behavior for our corrosion loop experiments has indicated that a long list of parameters is exerting an influence, directly and indirectly. The list presently includes the coolant inlet temperature, $T_{c i}$, the local coolant temperature, $T_{e}$, the local interface temperature, $T_{x / c}$, and the local heat flux, $\phi$. For our test system, these are not completely independent parameters. For example, both $T_{c}$ and $T_{x / c}$ depend upon $T_{c}, \phi$, and $V_{c}$; as mentioned previously, the effective oxide temperature must also be a function of $T_{x / c}, \phi$, and the instantaneous thickness of the film.

However, to simplify the present "preliminary correlation," we eventually focused on a data base of experiments conducted with a coolant inlet temperature, $\mathrm{T}_{c}$, between 39 and $49^{\circ} \mathrm{C}$; coolant velocities, $\mathrm{V}_{\mathrm{c}}$, between 25 and $28 \mathrm{~m} / \mathrm{s}$; and $\mathrm{pH}=5.0$. At present, the ANS core is expected to operate under these conditions. The tests that fulfill the conditions are CTESTs 8 , $10,14,15$, and 16 .

\section{RESULTS [METHOD (A)]}

As described above, this approach to correlation of the oxide growth rate data utilized directly the instantaneous oxide thicknesses calculated via the ANSDAT data reduction program. This program uses time-dependent data generated during the course of an experiment to calculate oxide thicknesses at seven thermocouple locations on the corrosion test section. Each of the seven locations on the specimen has at least one thermocouple monitoring the local test section temperature during an experiment. In addition, coolant flow rate, coolant inlet and outlet temperatures, and test section power are acquired as a function of time. With these parameters, assuming known physical properties of the aluminum and water, and an appropriate heat transfer coefficient, the local time-dependent oxide thickness is calculated at each position. Because positions 1 and 7 are located near the ends of the test section and are most subject to axial heat conduction effects, these positions are not utilized in any of the analyses described here. 
Each oxide thickness-vs-time profile was then fitted to a second-order polynomial in time. An example of one of these profiles, along with the appropriate curve fit, is shown in Fig. 11. By differentiating this curve, oxide growth rate information was generated. Instantaneous oxide growth rate data were also calculated using the raw oxide thickness data; however, such calculations tend to provide information with a large amount of scatter. The curve fit information was therefore used in the statistical analysis presented here.

Since the oxide thickness data were fitted with a second-order polynomial, the growth rate information generated from these curve fits always had the form of

$$
\mathrm{dx} / \mathrm{dt}=\mathrm{b}+\mathrm{ct} \text {. }
$$

These growth rates were used to examine the importance of various parameters on the oxidation process. Statistical analysis of the data was performed using the statistical analysis software package, SAS. In this preliminary analysis, only data from runs $8,10,14,15$, and 16 were used. These represent runs with a $\mathrm{pH}$ of 5 , inlet water temperatures from 39 to $49^{\circ} \mathrm{C}$, and coolant velocities from 25 to $28 \mathrm{~m} / \mathrm{s}$.

Many forms of correlations were examined, and only the simplest will be discussed here:

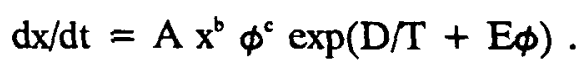

This equation follows the Arrhenius form and was fit to the data using various characteristic temperatures, $\mathrm{T}$, in an effort to determine the most appropriate instantaneous temperature with which to characterize the oxide formation process. Table 2 presents the results for several of these calculations in order of decreasing $R^{2}$ ( $R^{2}$ represents the correlation coefficient of the least-squares fit).

The results presented in Table 2 indicate that using a characteristic temperature representative of the oxide layer itself may provide the best method of correlating the data. This seems reasonable from a physical standpoint since one expects that the diffusion process through the oxide should be controlled by some characteristic temperature of the oxide layer rather than the fluid temperature, or even the interface temperature, which changes little with time. Additionally, one would not expect heat flux in and of itself to affect the growth rate other than the way in which it influences the physical condition of the oxide layer via temperatures, etc. The table also implies this behavior since eliminating the heat flux dependence in Eq. (6) only modestly reduces the effectiveness of the correlation. This tabulation, of course, is based on assumed models and could change if other models were examined. For the present, if the mean oxide temperature is involved, we are justified in dropping heat flux from the correlation. 
As an example of the performance of these correlations, Fig. 12 shows the predicted values of growth rate using Eq. (6) with $\mathrm{E}=0$ and the metal temperature vs growth rate values derived from the data. The fit appears reasonable for the low-growth-rate tests (where most of the data lie and where one should certainly prefer to operate the reactor), although it shows considerably more scatter for the high-growth-rate (and higher heat flux) runs. This could be a result of several factors: experimental data scatter, the goodness of fit of the assumed polynomial expression for $\mathrm{x}$ vs time, or the limitations imposed by the selected form of the variables chosen.

Results of these analyses are considered preliminary; however, a technique of predicting instantaneous growth rates using local conditions should provide the proper means of correlating the oxide growth rate data. In addition these results presently point to internal oxide temperatures as being a significant correlating parameter.

\section{RESULTS [METHOD (B)]}

In order to test the relevance of the assumed rate equation, plots of $\ln \mathrm{x}$ vs $\ln \mathrm{t}$ were made and examined for all of the OXCAL data sets. If there were no film on the specimen surface initially $\left(x_{0}=0\right)$, then these plots ideally should be linear with a slope of $1 /(n+1)$; that is, $n=$ (1/slope) - 1. However, for the case of an initial film, assumed with justification to be $2 \mu \mathrm{m}$ for our surface-treated aluminum specimens, such a plot will not be linear but will simply approach linearity at longer times.

All of our plots exhibited this curvature. The choice of the limiting slope was reasonably straightforward except perhaps for CTESTs 8 and 14, in which film growth was relatively slow. For each CTEST, a single value of the slope was picked from all three data sets. Even considering the personalized manner in which the slopes were determined, a relatively narrow range was found. These values are given in Table 3. The slope values range from 0.65 to 0.88 , with a mean of 0.74 and a standard deviation of 0.071 . Therefore, we designated $n=0.351$ and proceeded to step (B2), as described previously. The subset under consideration here, $39^{\circ} \mathrm{C}$ $\leq \mathrm{T}_{\mathrm{c}} \leq 49^{\circ} \mathrm{C}$ and $25 \mathrm{~m} / \mathrm{s} \leq \mathrm{V}_{\mathrm{c}} \leq 28 \mathrm{~m} / \mathrm{s}$, which includes CTESTs $8,10,14,15$, and 16, exhibited essentially the same average value for $n$. It should be reemphasized that in this assignment of $\mathrm{n}$, we presume to account implicitly for changes in the effective temperature of the product film during its growth. On the other hand, Method (A), which examines the rates of growth, can formulate other assumptions or assignments of $\mathbf{n}$ and can explicitly consider the consequences of the changing oxide temperatures. 
The determination of the rate constant, $k$, values for each of the data sets required additional plotting. From Eq. (2), it is evident that plots of $x^{n+1}$ vs $t$ should be linear with a slope of $(n+1) k$. In each of these cases, a straight line satisfactorily described the data, and a linear least-squares analysis was used to arrive at the proper slope and thence the value of $k$. Correlation coefficients or R-values" for these lines varied from 0.983 to 0.999 , with an average of 0.995 and a standard deviation of 0.0045 (the plots for CTEST 14 were omitted from this set). Table 4 presents a tabulation of the data sets, values of the designated parameters, and values of the derived rate constant, $k$, for each of the sets.

A number of empirical models were assessed with regard to their ability to predict the rate constant as a function of the four system variables given in Table 4. Initially, in order to assist in the analyses, a general statistical summary, including computation of the correlation coefficients for all the factors, was performed. Despite the fact that certain experimental results tend to remain outliers regardless of the model, satisfactory correlations were found for some variable combinations. In addition, it was observed that the chosen model sometimes grouped the data better than that indicated by the particular "R-squared" value (coefficient of determination) for the direct or linear fit. This implied that the variable combination was significant, even though the particular model was not optimal.

Almost identical levels of correlation were found for the three models:

$$
\begin{gathered}
\mathrm{k}=\underline{\mathrm{A}} \mathrm{T}_{\mathrm{c}}+\underline{\mathrm{B}} \mathrm{T}_{\mathrm{x} / \mathrm{c}}+\underline{\mathrm{C}} \phi-\underline{\mathrm{D}} /\left(\mathrm{T}_{\mathrm{c}}{ }^{3}\right)+\underline{\mathrm{E}}, \\
\mathrm{k}=\underline{\mathrm{A}} \mathrm{T}_{\mathrm{c}}+\underline{\mathrm{B}} \mathrm{T}_{\mathrm{c}}+\underline{\mathrm{C}} \mathrm{T}_{\mathrm{z} / \mathrm{c}}+\underline{\mathrm{D}} \phi+\underline{\mathrm{E}},
\end{gathered}
$$

and

$$
k=\underline{A} T_{d i}+\underline{B} T_{c}+\underline{C} T_{x / c}^{2}+\underline{D}\left(T_{x / c} \cdot \phi\right)+\underline{E} \phi^{2}+\underline{F},
$$

where the underlined multipliers $\underline{A}$ through $\underline{F}$ represent the coefficients determined by a leastsquares analysis. The R-square values for these linear fits were only 0.71 to 0.72 ; yet the plotted results grouped the data reasonably well, indicating that nonlinear fits based on these particular models would be more appropriate.

Better linear fits were obtained for models suggested by statistical methods available with SAS (e.g., the backward selection procedure). These models included the following:

\footnotetext{
“These numbers were obtained via the statistics package associated with the SIGMAPLOT Graphics Program (Jandel Scientific). They are stated to be "square roots of the coefficients of determination".
} 


$$
\ln \mathrm{k}=\underline{\mathrm{A}}\left(\mathrm{T}_{\mathrm{c}} \cdot \mathrm{T}_{\mathrm{c}}\right)+\underline{\mathrm{B}}\left(\mathrm{T}_{\mathrm{c}} \cdot \mathrm{T}_{\mathrm{x} / \mathrm{c}}\right)+\underline{\mathrm{C}}\left(\mathrm{T}_{\mathrm{ci}} \cdot \phi\right)+\underline{\mathrm{D}}
$$

and

$$
\ln \mathrm{k}=\underline{\mathrm{A}} \ln \mathrm{T}_{\mathrm{ci}}+\underline{\mathrm{B}} \ln \mathrm{T}_{\mathrm{c}}+\underline{\mathrm{C}} \ln \mathrm{T}_{\mathrm{x} / \mathrm{c}}+\underline{\mathrm{D}} \ln \phi+\underline{\mathrm{E}} .
$$

The R-square values for these models were 0.91 and 0.92 , signifying a better linear fit but not necessarily better data grouping, which has seemed to be roughly equivalent for any reasonable model optimized by least-squares that involved all four parameters.

However, for the purpose of establishing a preliminary correlation only for the rate constant, $k$, that can be used by the designers to predict on a conservative basis the thickness of the local product film on a fuel plate as a function of its thermal-hydraulic history, a simpler strategy was chosen, making use only of those data sets (CTESTs $8,10,14,15$, and 16) obtained under the anticipated ANS coolant conditions listed below.

1. Since for constant $T_{c}$ and $V_{c}$, the variables $T_{c}, \phi$, and $T_{x / c}$ in our experiments are interrelated, it is reasonable to expect that a correlation for $\mathbf{k}$ could be constructed on the basis of any two of them. The precise formulation in the present context is unknown, but a passable data grouping was obtained (without statistical aid) with several combinations.

2. A useful correlation of the rate data for CTESTs $8,10,14,15$, and 16 was obtained using the simple equation

$$
\ln \mathrm{k}=\mathrm{A}+\mathrm{B} /\left(\mathrm{T}_{\mathrm{c}}+10 \phi\right)
$$

A plot of the logarithm of the experimentally determined rate constants for these tests vs the rate function $1 /\left(T_{c}+10 \phi\right)$ is shown in Fig. 13. The majority of the data is acceptably grouped. For unknown reasons CTEST 15 exhibits lower growth rates than others of this set on this correlation basis and also on most correlations that were tested. The $\mathrm{k}$ values for CTEST 9 are also shown on this figure as an example of the higher oxide formation rates observed with higher coolant inlet temperatures.

3. The dashed line in Fig. 13 is drawn so as to yield conservative (higher) values for the rate constant (with the exception of the very low growth rates of CTEST 14, which in any case is so low as to pose no problems to the designers). The analytical representation of this line is given in classical Arrhenius format in an expression that constitutes our preliminary correlation. It is applicable under the restrictions discussed above:

$$
k=6.992 \mathrm{E} 5 \exp \left[-7592 /\left(\mathrm{T}_{\mathrm{c}}+10 \phi\right)\right] \quad \mu \mathrm{m}^{1.351} / \mathrm{h}
$$

4. A useful test of the correlation is to compare its predictions with the original film growth rate curves from which it was derived. Figures 14 to 17 illustrate these comparisons for CTESTs $8,10,15$, and 16 . As anticipated, because the correlation was chosen to give 
conservative values of $\mathrm{k}$, most of the thickness predictions were also conservative. The few that appear slightly nonconservative are best explained by the relatively poor conformance of that particular data set to the assigned model. For example, Fig. 17 shows an underprediction in the early stages of growth for CTEST 16 that seemed to be associated with start-up problems for this particular test, probably due to the very high power level in the specimen. It is noted in Fig. 18 that somewhat better agreement is obtained if it is assumed that the initial film thicknesses at the start of the experiment were slightly higher than $2 \mu \mathrm{m}$. Figure 19 shows the comparisons for CTEST 9, which was not included in the subset data base because of its higher coolant inlet temperature, $57^{\circ} \mathrm{C}$. As expected, the predicted rates in this instance were clearly higher than those in our correlation, based on lower inlet temperatures; this is one of the reasons why the ANS primary coolant system will be designed to provide a low inlet temperature.

An overview of the predictive capability of the preliminary correlation with respect to its data base is given in Fig. 20. In this figure, the measured film thicknesses on the test specimens at TC positions 2, 4, and 6 (calculated by OXCAL from the raw data) at several times during each test are plotted vs those values determined from the preliminary correlation. For the film thickness range of greatest practical importance, greater than $10 \mu \mathrm{m}$, the correlation is clearly conservative.

5. The applicability of the Arrhenius relation to describe these rate data may be coincidental, but it also reinforces the idea that the rate parameter $T_{c}+10 \phi$ is essentially an "effective temperature" for the rate process, as discussed earlier (note that $T_{c}+10 \phi$ is a rough estimator of the interface temperature, $T_{x c}$ ).

6. The values of $\mathbf{k}$ computed from this correlation would be used in the stepwise integration of Eq. (2), with $n=0.351$, to yield the local oxide thickness for any history of the two thermal-hydraulic parameters at a point on the cladding surface in the reactor core (within the range of the present data). While we express some concern that the interrelationships of the important thermal-hydraulic variables in the reactor core are different from those of our corrosion test loop, the overall differences are thought to be small. A larger data set involving a wider range of parameters will become available in the future and will be essential in defining a more accurate and a more generalized correlation.

It should be mentioned that an important assumption has not yet been addressed experimentally: that is, that the form of the basic rate equation itself does not change with time and 
fluctuations in parameters and that the reactive characteristics of the product film of a given thickness are independent of the manner in which it reached that thickness. Future corrosion test loop experiments will deal with this issue by conducting tests with varying parameters similar to those expected at a position of the fuel cladding in the ANS core.

\section{RESULTS [SPALLATION CRITERION]}

It was known from previous experiments performed during the development of the HFIR design that oxide thickness does not continue to increase indefinitely. Once a certain thickness is reached, the oxide layer spalls or sloughs off. In the HFIR experiments, it was surmised that spalling occurred when the oxide thickness reached about $50 \mu \mathrm{m}(2 \mathrm{mils})$. At first thought, the spalling would seem to be a desirable effect, since it limits the thermal resistance of the oxide layer and hence limits the increase of fuel temperature. However, our experiments, as did the HFIR experiments, have shown that the oxide spallation is followed by severe deformation of the aluminum surface and extensive subsurface voiding (see Fig. 10). Such damage reduces the effective thermal conductance of the clad and may even threaten clad integrity. Therefore, one would prefer to set operating conditions such that the oxide does not spall during the life of the core. Such an approach, however, requires a knowledge of the conditions that result in spalling, and our tests on the ANS corrosion loop have demonstrated that the notion of spalling at a particular thickness is false; the oxide thickness at which spalling takes place depends on other variables, including the heat flux.

We have now established a preliminary form of the conditions that lead to spalling, and although not yet complete, the new knowledge is sufficiently important to warrant inclusion in this report.

We have observed a very strong correlation between the increase in metal-oxide interface temperature and spallation. A similar limit was observed for the temperature drop across the oxide film, which is numerically almost equivalent since the metal temperature increase is due almost entirely to the thermal resistance of the oxide film. In 13 tests, with data gathered at a total of 61 different positions on 13 different specimens, there were no cases of spallation in the 44 cases where the metal temperature had risen less than $114^{\circ} \mathrm{C}$; conversely, out of 17 measurements with metal temperature increases of $115^{\circ} \mathrm{C}$ or more, only 3 did not spall (Fig. 21). Stated in terms of temperature drop across the oxide layer, the upper limit to avoid spallation is $119^{\circ} \mathrm{C}$ (Fig. 22). These results are based on tests carried out with $\mathrm{pH}$ ranging from 4.5 to 6.0 , 
heat flux from 5 to $20 \mathrm{MW} / \mathrm{m}^{2}$, and test section inlet temperatures from 39 to $80^{\circ} \mathrm{C}$. The only data excluded from tests carried out after the loop was in full working order were those from CTEST 7, during the course of which the $\mathrm{pH}$ was deliberately varied several times. We have, therefore, tentatively established the limits of operation to avoid spallation; it turns out that in nearly all cases, avoiding spallation sets a more stringent requirement than does the fuel temperature limit. Tables 5 and 6 list the data on which the limit is based.

The preceding paragraph is a statement of our observations. It is presumed that stresses in the oxide film associated with various growth processes, the temperature gradient, or stresses between the film and the underlying metal, are responsible for the spalling. The influence of heat flux was first discussed by W. R. Gambills, who pointed out that in the far smaller number of observations then available, including some HFIR and Advanced Test Reactor (ATR) data, oxide spallation took place when the temperature drop across the oxide reached 120 to $130^{\circ} \mathrm{C}$. He suggested that differential expansion within the film might be responsible. We plan further experiments to investigate whether this effect, differential expansion between metal and oxide (as suggested by C. D. West), or some other mechanism is responsible.

\section{CONCLUSIONS}

1. A preliminary correlation for conservative calculations of oxide thickness, and thence temperature increases in the cladding and fuel, under a certain range of ANS thermal-hydraulic conditions has been constructed. This correlation is

$$
\text { Oxide film growth rate }=\mathrm{dx} / \mathrm{dt}=\mathrm{k} / \mathrm{x}^{\mathrm{n}} \mu \mathrm{m} / \mathrm{h},
$$

where the exponent $\mathrm{n}$ and the rate constant $\mathrm{k}$ are given by

$$
\mathrm{n}=0.351 \text {, }
$$

and

$$
k=6.992 E 5 \exp \left[-7592 /\left(T_{c}+10 \phi\right)\right] \mu \mathrm{m}^{1351} / \mathrm{h}
$$

where

$$
\begin{aligned}
& \mathbf{k}=\text { rate constant from Eq. (1) and } \mathrm{Eq} . \text { (2) for } \mathrm{n}=0.351 \\
& \mathrm{~T}_{\mathrm{c}}=\text { Local coolant temperature, } \mathrm{K} \\
& \phi=\text { Local heat flux, } \mathrm{MW} / \mathrm{m}^{2} \text {. }
\end{aligned}
$$

2. Continuing efforts to expand the data base and construct physically based film growth models and analyses will be essential to provide increased understanding of this complicated reaction, as well as to provide better predictive capability for a variety of conditions. 
3. It has been found that spallation of the oxide film (a highly undesirable process) does not take place if the increase in metal temperature at the oxide-metal interface during the test is less than $114^{\circ} \mathrm{C}$. The increase in metal temperature is largely due to the temperature drop across the oxide film, and the criterion for avoiding spallation is therefore a function of heat flux as well as film thickness.

\section{ACKNOWLEDGMENTS}

The authors would like to thank the many contributors to the ANS Corrosion Test Loop Program. In particular, appreciation is due M. T. McFee for his continuing efforts in the operation of the loop, J. A. Crabtree and C. K. Bayne for their assistance with data handling and statistics, and W. R. Gambill for numerous and continuing contributions. We also thank J. F. King, J. D. McNabb, L. D. Chitwood, and R. R. Leedy for their able support in the fabrication of the test sections and specimen examinations. 


\section{REFERENCES}

1. J. C. Griess et al., Effect of Heat Flux on the Corrosion of Aluminum by Water, Part III, Final Report on Tests Relative to the High-Flux Isotope Reactor, ORNL-3230, Martin Marietta Energy Systems, Inc., Oak Ridge Natl. Lab., December 1961.

2. J. C. Griess, H. C. Savage, and J. L. English, Effect of Heat Flux on the Corrosion of Aluminum by Water, Part IV, Tests Relative to the Advanced Test Reactor and Correlation with Previous Results, ORNL-3541, Martin Marietta Energy Systems, Inc., Oak Ridge Natl. Lab., February 1964.

3. R. E. Pawel, On the Kinetics of the Aluminum-Water Reaction During Exposure in High-Heat Flux Test Loops, I, A Computer Program for Oxidation Calculations, ORNL/TM-10602, Martin Marietta Energy Systems, Inc., Oak Ridge Natl. Lab., January 1988.

4. D. L. Selby, R. M. Harrington, and F. J. Peretz, Advanced Neutron Source (ANS) Project Annual Report-April 1988-September 1989, ORNL-6574, Martin Marietta Energy Systems, Inc., Oak Ridge Natl. Lab., December 1989.

5. G. H. Hanson, J. C. Griess, R. E. Pawel, and J. M. Ryskamp, pp. 9, 10 in Report of the Advanced Neutron Source (ANS) Aluminum Cladding Corrosion Workshop-November 16-17, 1988-Idaho Falls, Idaho, ORNL/CONF-8811203, Martin Marietta Energy Systems, Inc., Oak Ridge Natl. Lab., February 1989. 
Table 1. Corrosion test loop: completed tests and parameters

\begin{tabular}{|c|c|c|c|c|c|c|c|c|c|c|c|c|c|c|}
\hline \multirow[b]{2}{*}{ PARAMETERS } & \multicolumn{14}{|c|}{ TEST NUMBER } \\
\hline & CTEST3 & CTEST4 & CTEST5 & CTEST6 & CTEST7 & CTEST8 & СTEST9 & CTESTIO & CTEST11 & CTEST12 & CTEST13 & CTEST14 & CTEST15 & CTEST16 \\
\hline $\begin{array}{l}\text { STARTED } \\
\text { COMPLETED } \\
\text { TIME (DAYS) }\end{array}$ & $\begin{array}{c}6 / 27 / 88 \\
6 / 30 / 88 \\
3\end{array}$ & $\begin{array}{c}8 / 19 / 88 \\
8 / 24 / 88 \\
5\end{array}$ & $\begin{array}{c}9 / 8 / 88 \\
9 / 22 / 88 \\
15\end{array}$ & $\begin{array}{c}12 / 13 / 8 \\
12 / 23 / 8 \\
9\end{array}$ & $\begin{array}{c}1 / 31 / 89 \\
2 / 23 / 89 \\
23\end{array}$ & \begin{tabular}{|c|}
$3 / 7 / 89$ \\
$3 / 23 / 89$ \\
14
\end{tabular} & $\begin{array}{c}3 / 28 / 89 \\
4 / 7 / 89 \\
10\end{array}$ & $\begin{array}{l}4 / 13 / 89 \\
4 / 25 / 89 \\
12\end{array}$ & $\begin{array}{c}5 / 3 / 89 \\
5 / 18 / 89 \\
15\end{array}$ & $\left|\begin{array}{c}6 / 27 / 89 \\
6 / 29 / 89 \\
3\end{array}\right|$ & \begin{tabular}{|c|}
$7 / 19 / 89$ \\
$8 / 02 / 89$ \\
14
\end{tabular} & \begin{tabular}{|c|}
$8 / 10 / 89$ \\
$8 / 31 / 89$ \\
21
\end{tabular} & \begin{tabular}{|c|}
$9 / 12 / 89$ \\
$10 / 6 / 89$ \\
24
\end{tabular} & $\begin{array}{c}10 / 17 / 9 \\
10 / 20 / 9 \\
2\end{array}$ \\
\hline $\mathbf{P H}$ & 6.0 & $5.0+$ & 5.0 & 4.5 & $5.0 / 4.5$ & 5.0 & 5.0 & 5.0 & 5.0 & 6.0 & 5.0 & 5.0 & 5.0 & 5.0 \\
\hline $\begin{array}{l}\text { CONDUCTIVITY } \\
\text { (US } / M)\end{array}$ & 140 & $400+$ & 460 & 1250 & $\begin{array}{r}500- \\
1500\end{array}$ & $500+$ & 500 & 500 & $550-$ & 140 & 600 & $600 ?$ & 520 & 550 \\
\hline INLET $\operatorname{TEMP}\left({ }^{\circ} \mathrm{C}\right)$ & 80 & 79 & 75 & 80 & 80 & 43 & 57 & 39 & 39 & 80 & 67 & 49 & 49 & 49 \\
\hline VELOCITY $(\mathrm{M} / \mathrm{S})$ & 27.1 & 27.7 & 12.8 & 24.2 & 24.2 & 25.4 & 25.5 & 25.5 & 19.2 & 28.0 & 27.8 & 25.6 & 25.6 & 25.6 \\
\hline AV. POWER (KW) & 42.0 & 41.6 & 19.0 & 41.8 & 41.8 & 42.0 & 43.0 & 56.0 & 42.4 & 43.0 & 37.7 & 22.3 & 44.8 & 67.0 \\
\hline $\begin{array}{l}\text { HT. FLUX }\left(M W / M^{2}\right) \\
\text { AVERAGE } \\
\text { POS. } 2 \\
\text { POS. } 4 \\
\text { POS. } 6\end{array}$ & $\begin{array}{l}11.6 \\
11.3 \\
11.6 \\
12.0\end{array}$ & $\begin{array}{l}11.6 \\
11.0 \\
11.5 \\
12.5\end{array}$ & $\begin{array}{l}5.3 \\
5.2 \\
5.3 \\
5.5\end{array}$ & $\begin{array}{l}11.6 \\
11.4 \\
11.6 \\
12.0\end{array}$ & $\begin{array}{l}11.6 \\
10.9 \\
11.5 \\
12.4\end{array}$ & $\begin{array}{l}11.7 \\
11.3 \\
11.7 \\
12.1\end{array}$ & $\begin{array}{l}12.0 \\
11.4 \\
12.1 \\
12.7\end{array}$ & $\begin{array}{l}15.7 \\
14.5 \\
15.5 \\
17.2\end{array}$ & $\begin{array}{l}11.9 \\
11.6 \\
11.9 \\
12.3\end{array}$ & $\begin{array}{l}11.9 \\
11.4 \\
11.8 \\
12.4\end{array}$ & $\begin{array}{l}10.6 \\
10.1 \\
10.6 \\
11.1\end{array}$ & $\begin{array}{l}6.2 \\
6.2 \\
6.2 \\
6.2\end{array}$ & $\begin{array}{l}12.5 \\
12.3 \\
12.6 \\
12.8\end{array}$ & $\begin{array}{l}18.7 \\
17.3 \\
18.2 \\
20.2\end{array}$ \\
\hline $\begin{array}{ll}\text { COOLANT } & \left({ }^{\circ} \mathrm{C}\right) \\
\text { POS. } 2 & \\
\text { POS. } 4 & \\
\text { POS. } 6 & \end{array}$ & $\begin{array}{l}83 \\
90 \\
96\end{array}$ & $\begin{array}{l}83 \\
90 \\
97\end{array}$ & $\begin{array}{l}79 \\
85 \\
92\end{array}$ & $\begin{array}{r}84 \\
93 \\
101\end{array}$ & $\begin{array}{l}84 \\
91 \\
99\end{array}$ & $\begin{array}{l}47 \\
56 \\
64\end{array}$ & $\begin{array}{l}61 \\
70 \\
78\end{array}$ & $\begin{array}{l}45 \\
56 \\
67\end{array}$ & $\begin{array}{l}44 \\
55 \\
66\end{array}$ & $\begin{array}{l}84 \\
92 \\
99\end{array}$ & $\begin{array}{l}71 \\
78 \\
84\end{array}$ & $\begin{array}{l}51 \\
56 \\
60\end{array}$ & $\begin{array}{l}53 \\
62 \\
71\end{array}$ & $\begin{array}{l}56 \\
69 \\
82\end{array}$ \\
\hline $\begin{array}{l}\text { INTERFACE }\left({ }^{\circ} \mathrm{C}\right) \\
\text { POS. } 2 \\
\text { POS. } 4 \\
\text { POS. } 6\end{array}$ & $\begin{array}{l}147 \\
155 \\
163\end{array}$ & $\begin{array}{l}146 \\
154 \\
165\end{array}$ & $\begin{array}{l}136 \\
143 \\
150\end{array}$ & $\begin{array}{l}156 \\
164 \\
173\end{array}$ & $\begin{array}{l}146 \\
156 \\
168\end{array}$ & $\begin{array}{l}127 \\
135 \\
143\end{array}$ & $\begin{array}{l}136 \\
146 \\
156\end{array}$ & $\begin{array}{l}146 \\
158 \\
175\end{array}$ & $\begin{array}{l}147 \\
155 \\
165\end{array}$ & $\begin{array}{l}148 \\
156 \\
166\end{array}$ & $\begin{array}{l}131 \\
139 \\
147\end{array}$ & $\begin{array}{r}96 \\
99 \\
103\end{array}$ & $\begin{array}{l}136 \\
144 \\
152\end{array}$ & $\begin{array}{l}169 \\
181 \\
201\end{array}$ \\
\hline FE-RICH LAYER? & NONE & NONE & LIGHT & HEAVY & HEAVY & LIGHT & LIGHT & HEAVY & HEAVY & NONE & SLIGHT & SLIGHT & HEAVY & SLIGHT \\
\hline $\begin{array}{l}\text { OXIDE PRODUCT } \\
\text { (> TRIESS? ) } \\
\text { SPALL AT TE-6? }\end{array}$ & YES & YES & SAME & No & $\begin{array}{l}\text { NO } \\
\text { YES }\end{array}$ & $\begin{array}{l}\text { No } \\
\text { No }\end{array}$ & $\begin{array}{l}\text { YES } \\
\text { YES }\end{array}$ & No & $\begin{array}{l}\text { No } \\
\text { No }\end{array}$ & YES & YES & No & No & $\begin{array}{l}\text { YES } \\
\text { YES }\end{array}$ \\
\hline
\end{tabular}


Table 2. Evaluation of characteristic temperatures in Eq. (6)

\begin{tabular}{|c|c|c|c|}
\hline \multicolumn{3}{|c|}{$\begin{array}{c}\text { Parameters included in calculation } \\
\end{array}$} & \multirow[b]{2}{*}{$\mathrm{R}^{2}$} \\
\hline Temperature & Heat flux & Oxide thickness & \\
\hline$T_{m / x}$ & $\phi$ & $\mathbf{x}$ & 0.868 \\
\hline$T_{m / x}$ & $\phi(E=0)$ & $\mathbf{x}$ & 0.868 \\
\hline$T_{\text {xavg }}$ & $\phi$ & $\mathbf{x}$ & 0.866 \\
\hline$T_{x, \text { avg }}$ & $\phi(c=0)$ & $\mathbf{x}$ & 0.866 \\
\hline $\mathrm{T}_{\mathrm{x} \text { avg }}$ & $\phi(E=0)$ & $\mathbf{x}$ & 0.865 \\
\hline$T_{\text {xavg }}$ & & $\mathbf{x}$ & 0.861 \\
\hline$T_{m / x}$ & & $\mathbf{x}$ & 0.860 \\
\hline$T_{x / c}$ & $\phi$ & $\mathbf{x}$ & 0.857 \\
\hline$T_{x / c}$ & $\phi(\mathrm{c}=0)$ & $\mathbf{x}$ & 0.855 \\
\hline $\mathrm{T}_{\mathrm{c}}$ & $\phi$ & $\mathbf{x}$ & 0.853 \\
\hline$T_{c}$ & $\phi(c=0)$ & $\mathbf{x}$ & 0.852 \\
\hline \multirow[t]{2}{*}{$T_{x / c}$} & $\phi(E=0)$ & $\mathbf{x}$ & 0.846 \\
\hline & $\phi(c=0)$ & $\mathbf{x}$ & 0.845 \\
\hline$T_{x / c}$ & & $\mathbf{x}$ & 0.844 \\
\hline \multirow[t]{4}{*}{$\mathrm{T}_{\mathrm{c}}$} & $\phi(E=0)$ & $\mathbf{x}$ & 0.826 \\
\hline & $\phi(c=0)$ & & 0.826 \\
\hline & $\phi(E=0)$ & $\mathbf{x}$ & 0.808 \\
\hline & $\phi(E=0)$ & & 0.784 \\
\hline
\end{tabular}


Table 3. Measured slopes of $\ln \mathrm{x}$ vs $\ln \mathrm{t}$ curves from OXCAL

\begin{tabular}{lc}
\hline & Slope \\
CTEST No. & $1 /(\mathrm{n}+1)$ \\
\hline 4 & \\
5 & 0.78 \\
7 & 0.70 \\
8 & 0.65 \\
9 & \\
10 & 0.77 \\
11 & 0.78 \\
13 & 0.88 \\
14 & 0.74 \\
15 & \\
16 & 0.72 \\
& 0.66 \\
Average & \\
Std. Dev. & \\
n & 0.74 \\
\end{tabular}


Table 4. OXCAL-generated data set for rate correlation determinations

\begin{tabular}{|c|c|c|c|c|c|}
\hline $\begin{array}{l}\text { Expt. No. } \\
\text { TC Pos. }\end{array}$ & $\begin{array}{l}T_{c i} \\
(K)\end{array}$ & $\begin{array}{l}T_{c} \\
(K)\end{array}$ & $\begin{array}{l}\text { Flux } \\
\left(\mathrm{MW} / \mathrm{m}^{2}\right)\end{array}$ & $\begin{array}{l}T_{x / c} \\
(K)\end{array}$ & $\underset{\left(\mu \mathrm{m}^{1.351} / \mathrm{h}\right)}{\mathbf{k}}$ \\
\hline $4-2$ & 352 & 356 & 11.0 & 419 & 0.389 \\
\hline $4-4$ & 352 & 363 & 11.5 & 427 & 0.597 \\
\hline $4-6$ & 352 & 370 & 12.5 & 436 & 0.991 \\
\hline $5-2$ & 348 & 352 & 5.2 & 409 & 0.0844 \\
\hline $5-4$ & 348 & 358 & 5.3 & 416 & 0.131 \\
\hline $5-6$ & 348 & 365 & 5.5 & 423 & 0.187 \\
\hline $7-2$ & 353 & 356 & 11.2 & 421 & 0.262 \\
\hline $7-4$ & 353 & 364 & 11.6 & 429 & 0.370 \\
\hline $7-6$ & 353 & 372 & 12.1 & 438 & 0.522 \\
\hline $8-2$ & 316 & 320 & 11.3 & 400 & 0.0154 \\
\hline $8-4$ & 316 & 328.5 & 11.7 & 408 & 0.0196 \\
\hline $8-6$ & 316 & 337 & 12.1 & 416 & 0.0349 \\
\hline $9-2$ & 330 & 334 & 11.4 & 409 & 0.0955 \\
\hline $9-4$ & 330 & 343 & 12.1 & 419 & 0.181 \\
\hline $9-6$ & 330 & 351 & 12.7 & 429 & 0.287 \\
\hline $10-2$ & 312 & 318 & 14.5 & 419 & 0.0391 \\
\hline $10-4$ & 312 & 329 & 15.5 & 431 & 0.0918 \\
\hline $10-6$ & 312 & 340 & 17.2 & 448 & 0.192 \\
\hline $11-2$ & 311 & 317 & 11.6 & 420 & 0.0159 \\
\hline $11-4$ & 311 & 328 & 11.9 & 428 & 0.0304 \\
\hline $11-6$ & 311 & 339 & 12.3 & 437 & 0.0620 \\
\hline $13-2$ & 340 & 344 & 10.1 & 404 & 0.0977 \\
\hline $13-4$ & 340 & 351 & 10.6 & 412 & 0.142 \\
\hline $13-6$ & 340 & 357 & 11.1 & 420 & 0.181 \\
\hline $14-2$ & 322 & 324 & 6.2 & 368 & 0.005 \\
\hline $14-4$ & 322 & 329 & 6.2 & 372 & 0.005 \\
\hline $14-6$ & 322 & 333.5 & 6.2 & 376 & 0.005 \\
\hline $15-2$ & 322 & 326 & 12.3 & 409 & 0.0126 \\
\hline $15-4$ & 322 & 335 & 12.6 & 417 & 0.0193 \\
\hline $15-6$ & 322 & 344 & 12.8 & 425 & 0.0280 \\
\hline $16-2$ & 322 & 329 & 17.3 & 442 & 0.166 \\
\hline $16-4$ & 322 & 342 & 18.2 & 454 & 0.246 \\
\hline $16-6$ & 322 & 355 & 20.2 & 474 & 0.608 \\
\hline
\end{tabular}


Table 5. List of changes in metal-oxide interface temperatures at time of spalling or end of run for all CTESTs and their TCs

\begin{tabular}{|c|c|c|c|c|c|c|c|c|c|}
\hline $\begin{array}{c}\text { CTEST } \\
\text { No. }\end{array}$ & $\begin{array}{c}\text { TC } \\
\text { position }\end{array}$ & $\begin{array}{l}\text { Time } \\
\text { (h) }\end{array}$ & $\begin{array}{l}\text { Change } \\
\mathrm{I}_{m}\left({ }^{\circ} \mathrm{C}\right)\end{array}$ & Spalled & $\begin{array}{c}\text { CTEST } \\
\text { No. }\end{array}$ & $\begin{array}{c}\text { TC } \\
\text { position }\end{array}$ & $\begin{array}{l}\text { Time } \\
\text { (h) }\end{array}$ & $\begin{array}{l}\text { Change } \\
\mathrm{I}_{m}\left({ }^{\circ} \mathrm{C}\right)\end{array}$ & Spalled \\
\hline 14 & 3 & 449.2 & 4 & No & 5 & 6 & 327.5 & 62 & No \\
\hline 14 & 6 & 449.2 & 4 & No & 11 & 6 & 351.8 & 66 & No \\
\hline 14 & 2 & 449.2 & 4 & No & 13 & 2 & 333.5 & 72 & No \\
\hline 14 & 5 & 449.2 & 4 & No & 9 & 3 & 234.3 & 77 & No \\
\hline 14 & 4 & 449.2 & 4 & No & 10 & 4 & 280.3 & 87 & No \\
\hline 11 & 2 & 351.8 & 16 & No & 13 & 3 & 333.6 & 90 & No \\
\hline 8 & 2 & 330.2 & 17 & No & 3 & 2 & 63.0 & 99 & No \\
\hline 6 & 2 & 221.4 & 17 & No & 13 & 4 & 333.6 & 99 & No \\
\hline 8 & 3 & 330.2 & 19 & No & 12 & 2 & 49.4 & 100 & No \\
\hline 11 & 3 & 351.8 & 23 & No & 9 & 4 & 234.3 & 102 & No \\
\hline 8 & 4 & 330.2 & 25 & No & 4 & 2 & 112.0 & 102 & No \\
\hline 15 & 2 & 566.6 & 26 & No & 16 & 5 & 57.5 & 106 & No \\
\hline 6 & 4 & 221.4 & 27 & No & 12 & 3 & 49.4 & 113 & No \\
\hline 5 & 2 & 327.5 & 28 & No & 3 & 5 & 45.0 & 114 & Yes \\
\hline 8 & 5 & 330.2 & 31 & No & 13 & 5 & 333.6 & 115 & No \\
\hline 16 & 2 & 57.5 & 32 & No & 4 & 3 & 112.8 & 119 & Yes \\
\hline 10 & 2 & 280.3 & 33 & No & 3 & 4 & 55.0 & 119 & Yes \\
\hline 11 & 4 & 351.8 & 33 & No & 3 & 3 & 59.3 & 119 & Yes \\
\hline 6 & 5 & 221.4 & 34 & No & 3 & 6 & 41.0 & 119 & Yes \\
\hline 15 & 3 & 566.6 & 34 & No & 4 & 6 & 36.5 & 122 & Yes \\
\hline 15 & 4 & 566.6 & 37 & No & 4 & 5 & 70.8 & 122 & Yes \\
\hline 5 & 3 & 327.5 & 37 & No & 12 & 4 & 43.8 & 122 & Yes \\
\hline 6 & 6 & 221.4 & 38 & No & 4 & 4 & 89.5 & 126 & Yes \\
\hline 8 & 6 & 330.2 & 41 & No & 9 & 5 & 234.3 & 134 & No \\
\hline 5 & 4 & 327.5 & 43 & No & 13 & 6 & 333.6 & 138 & No \\
\hline 9 & 2 & 234.3 & 50 & No & 12 & 5 & 43.4 & 153 & Yes \\
\hline 15 & 6 & 566.6 & 52 & No & 10 & 6 & 192.8 & 153 & Yes \\
\hline 5 & 5 & 327.5 & 54 & No & 9 & 6 & 211.5 & 153 & Yes \\
\hline 16 & 3 & 57.5 & 54 & No & 12 & 6 & 40.1 & 161 & Yes \\
\hline 16 & 5 & 57.5 & 56 & No & 16 & 6 & 57.5 & 164 & Yes \\
\hline 11 & 5 & 351.8 & 60 & No & & & & & \\
\hline
\end{tabular}


Table 6. List of oxide temperature differences at time of spalling or end of run for all CTESTs and their TCs

\begin{tabular}{|c|c|c|c|c|c|c|c|c|c|c|}
\hline $\begin{array}{c}\text { CTEST } \\
\text { No. }\end{array}$ & $\begin{array}{c}\text { TC } \\
\text { position }\end{array}$ & $\begin{array}{c}\text { Time } \\
\text { (h) }\end{array}$ & $\begin{array}{l}\text { Change } \\
\left.\mathrm{T}_{x}{ }^{\circ} \mathrm{C}\right)\end{array}$ & Spalled & & $\begin{array}{c}\text { CTEST } \\
\text { No. }\end{array}$ & $\begin{array}{c}\text { TC } \\
\text { position }\end{array}$ & $\begin{array}{c}\text { Time } \\
\text { (h) }\end{array}$ & $\begin{array}{l}\text { Change } \\
\left.\mathrm{T}_{x}{ }^{\circ} \mathrm{C}\right)\end{array}$ & Spalled \\
\hline 14 & 3 & 449.2 & 9 & No & & 16 & 3 & 57.5 & 72 & No \\
\hline 14 & 6 & 449.2 & 9 & No & & 16 & 4 & 57.5 & 73 & No \\
\hline 14 & 2 & 449.2 & 9 & No & & 13 & 2 & 333.5 & 77 & No \\
\hline 14 & 5 & 449.2 & 9 & No & & 9 & 3 & 234.3 & 88 & No \\
\hline 14 & 4 & 449.2 & 9 & No & & 13 & 3 & 333.6 & 94 & No \\
\hline 8 & 2 & 330.2 & 27 & No & & 10 & 4 & 280.3 & 98 & No \\
\hline 6 & 2 & 221.4 & 28 & No & & 13 & 4 & 333.6 & 101 & No \\
\hline 11 & 2 & 351.8 & 28 & No & & 3 & 2 & 63.0 & 105 & No \\
\hline 8 & 3 & 330.2 & 30 & No & & 4 & 2 & 112.0 & 108 & No \\
\hline 5 & 2 & 327.5 & 33 & No & . & 9 & 4 & 234.3 & 110 & No \\
\hline 11 & 3 & 351.8 & 34 & No & & 12 & 2 & 49.4 & 114 & No \\
\hline 8 & 4 & 330.2 & 35 & No & & 16 & 5 & 57.5 & 114 & No \\
\hline 6 & 4 & 221.4 & 36 & No & & 13 & 5 & 333.6 & 116 & No \\
\hline 15 & 2 & 566.6 & 37 & No & & 3 & 5 & 45.0 & 119 & Yes \\
\hline 8 & 5 & 330.2 & 40 & No & & 3 & 6 & 41.0 & 122 & Yes \\
\hline 5 & 3 & 327.5 & 42 & No & & 4 & 3 & 112.8 & 124 & Yes \\
\hline 11 & 4 & 351.8 & 42 & No & & 3 & 3 & 59.3 & 124 & Yes \\
\hline 6 & 5 & 221.4 & 42 & No & & 3 & 4 & 55.0 & 125 & Yes \\
\hline 15 & 3 & 566.6 & 45 & No & & 4 & 6 & 56.5 & 125 & Yes \\
\hline 6 & 6 & 221.4 & 46 & No & & 4 & 5 & 70.8 & 125 & Yes \\
\hline 15 & 4 & 566.6 & 46 & No & & 12 & 3 & 49.4 & 126 & No \\
\hline 5 & 4 & 327.5 & 48 & No & & 4 & 4 & 89.5 & 131 & Yes \\
\hline 8 & 6 & 330.2 & 50 & No & & 12 & 4 & 43.8 & 132 & Yes \\
\hline 10 & 2 & 280.3 & 52 & No & & 13 & 6 & 333.6 & 137 & No \\
\hline 16 & 2 & 57.5 & 53 & No & & 9 & 5 & 234.3 & 138 & No \\
\hline 5 & 5 & 327.5 & 58 & No & & 10 & 6 & 192.8 & 149 & Yes \\
\hline 15 & 6 & 566.6 & 59 & No & & 9 & 6 & 211.5 & 154 & Yes \\
\hline 9 & 2 & 234.3 & 64 & No & & 12 & 5 & 43.4 & 159 & Yes \\
\hline 11 & 5 & 351.8 & 64 & No & & 16 & 6 & 57.5 & 163 & Yes \\
\hline 5 & 6 & 327.5 & 65 & No & & 12 & 6 & 40.1 & 165 & Yes \\
\hline 11 & 6 & 351.8 & 70 & No & & & & & & \\
\hline
\end{tabular}


ORNL.PHOTO-8154-89



Fig. 1. Photograph of ANS corrosion loop test facility. 


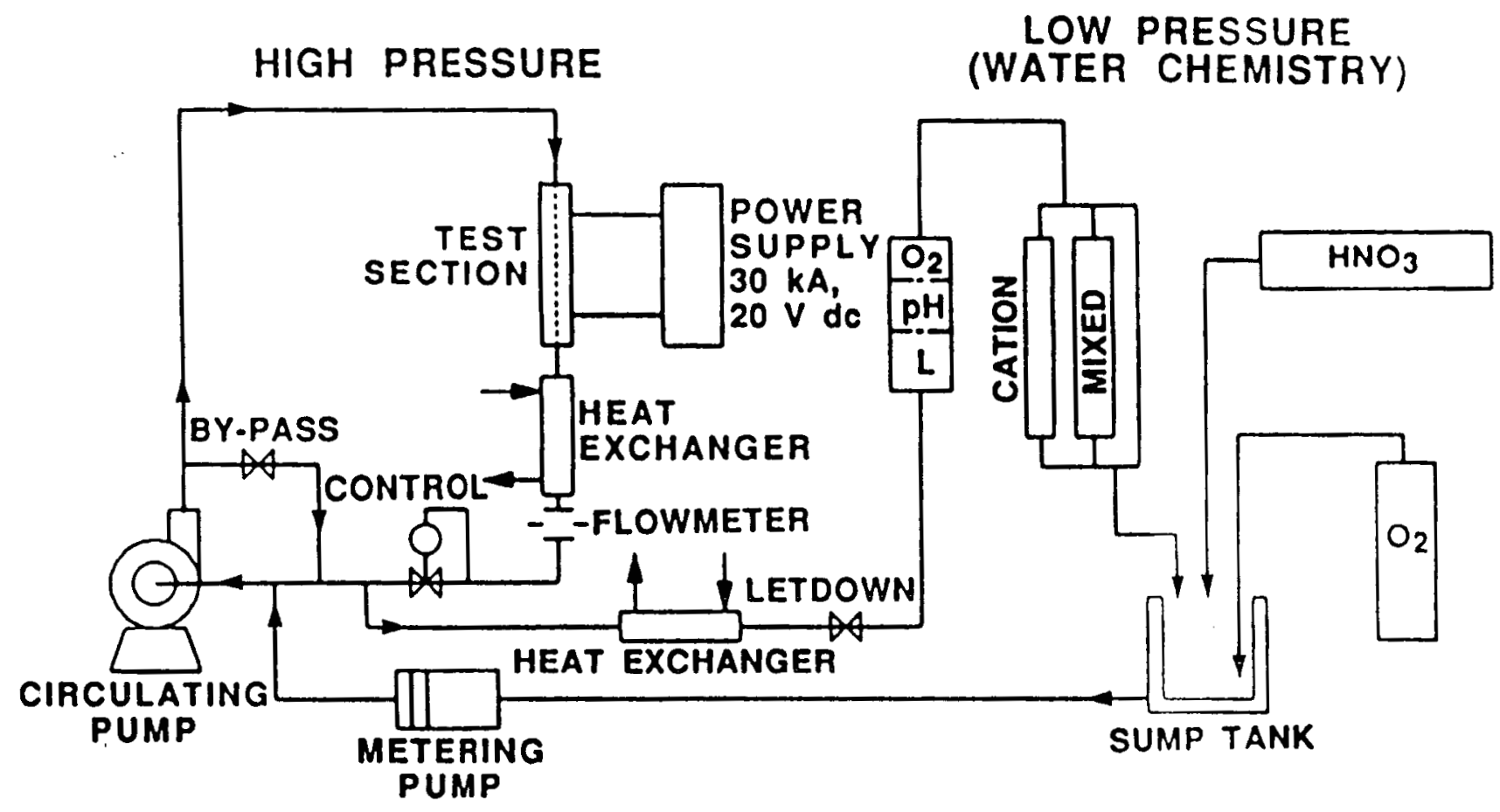

FEATURES:

- 304 L SS THROUGHOUT

7-MPa (1000-PSI) OPERATION

35-m/s COOLANT FLOW

- 65-kW SPECIMEN POWER (325 kW FOR T/H)

20-MW/m² HEAT FLUX FOR

CORROSION TESTS (EST. 32

CONTROL OF COOLANT TEMPERATURES

MW/m 2 FOR THERMAL-HYDRAULIC

- COMPUTERIZED CONTROL, SAFETY, AND MW/m2
TESTS RECORDING

Fig. 2. Corrosion test loop flow schematic. 


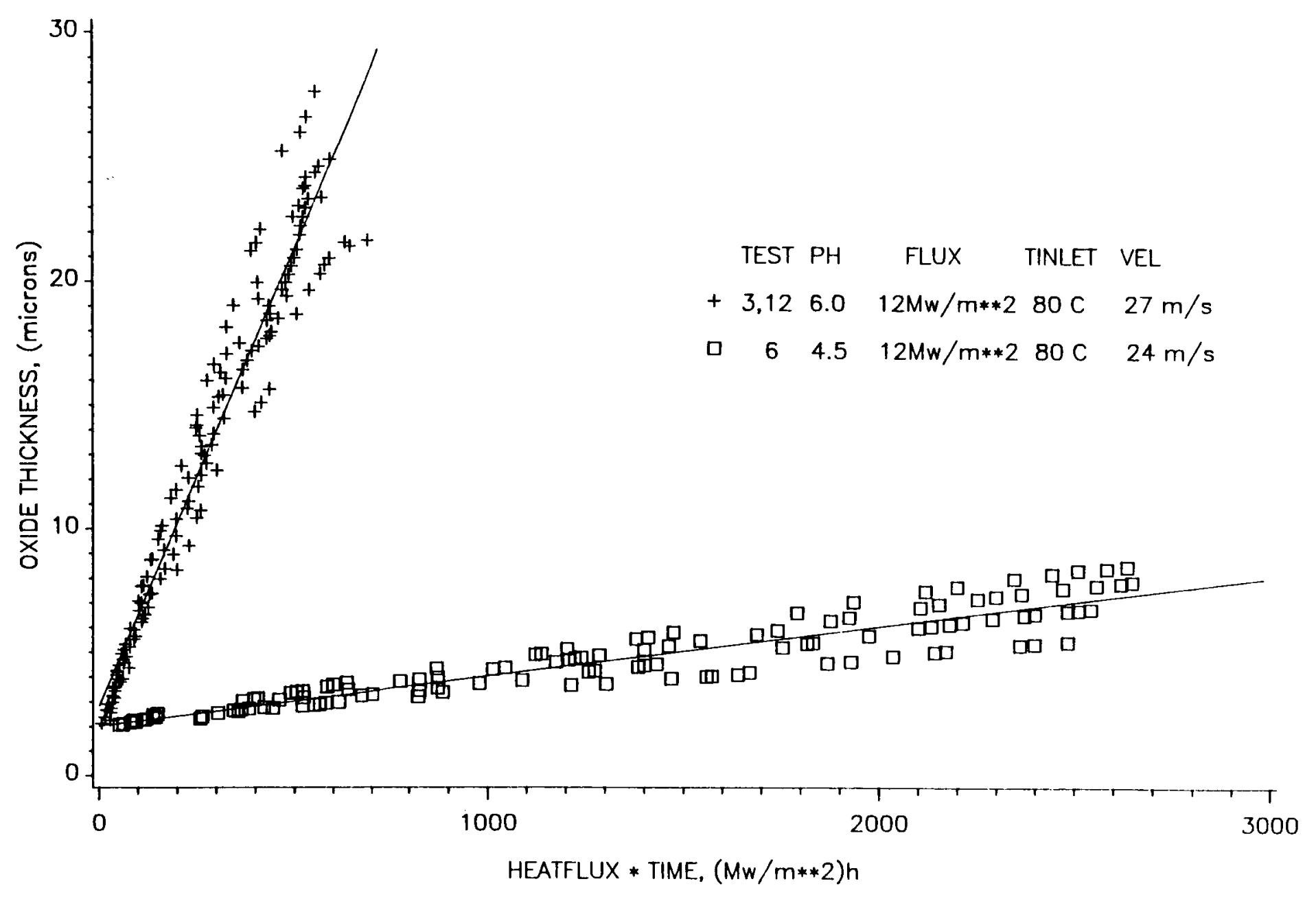

JAC-26MAR90

Fig. 3. Thickness-vs-time results at different coolant pH. 


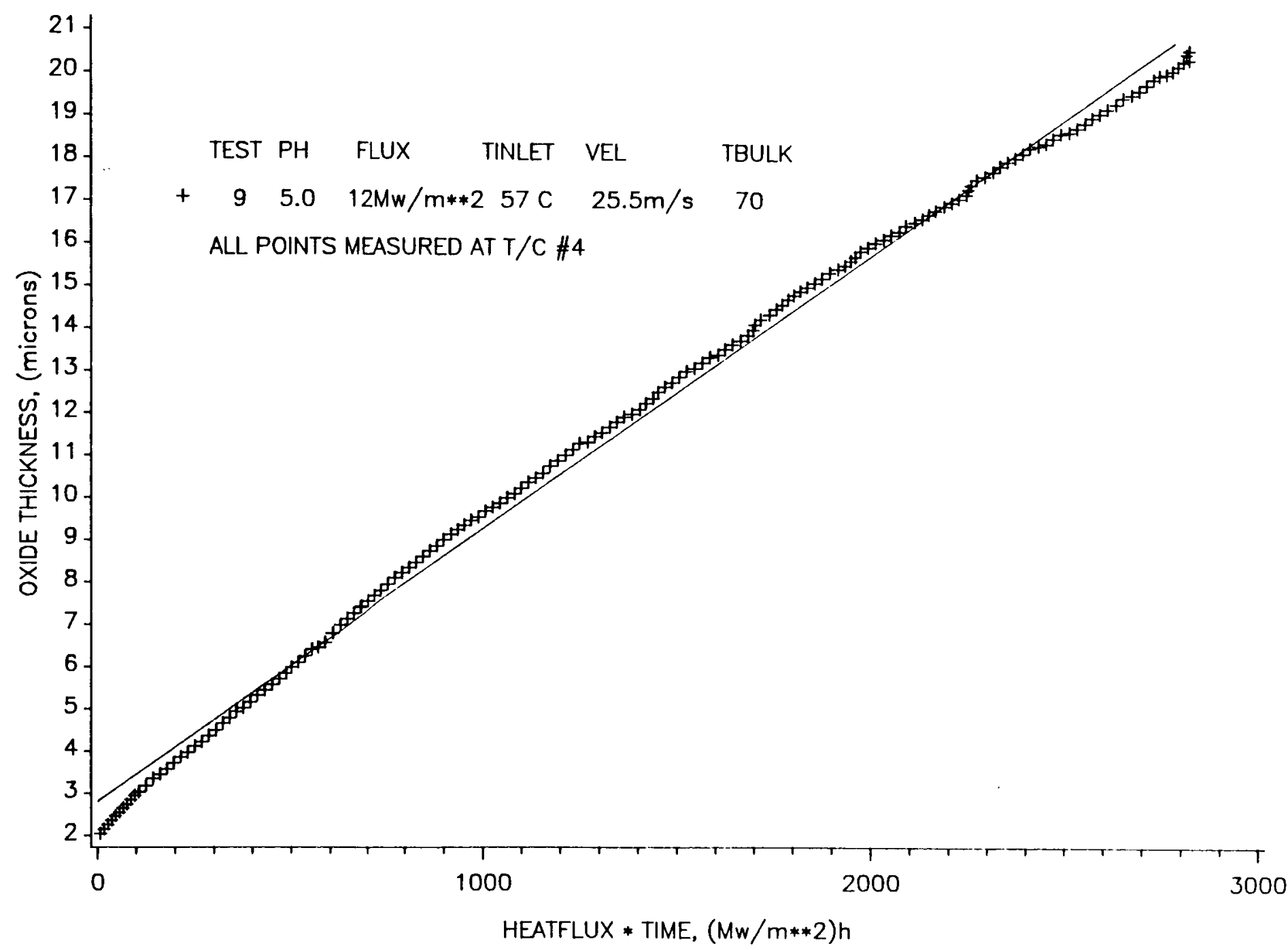

Fig. 4. Oxide thickness vs time for CTEST 9 and TC-4. 


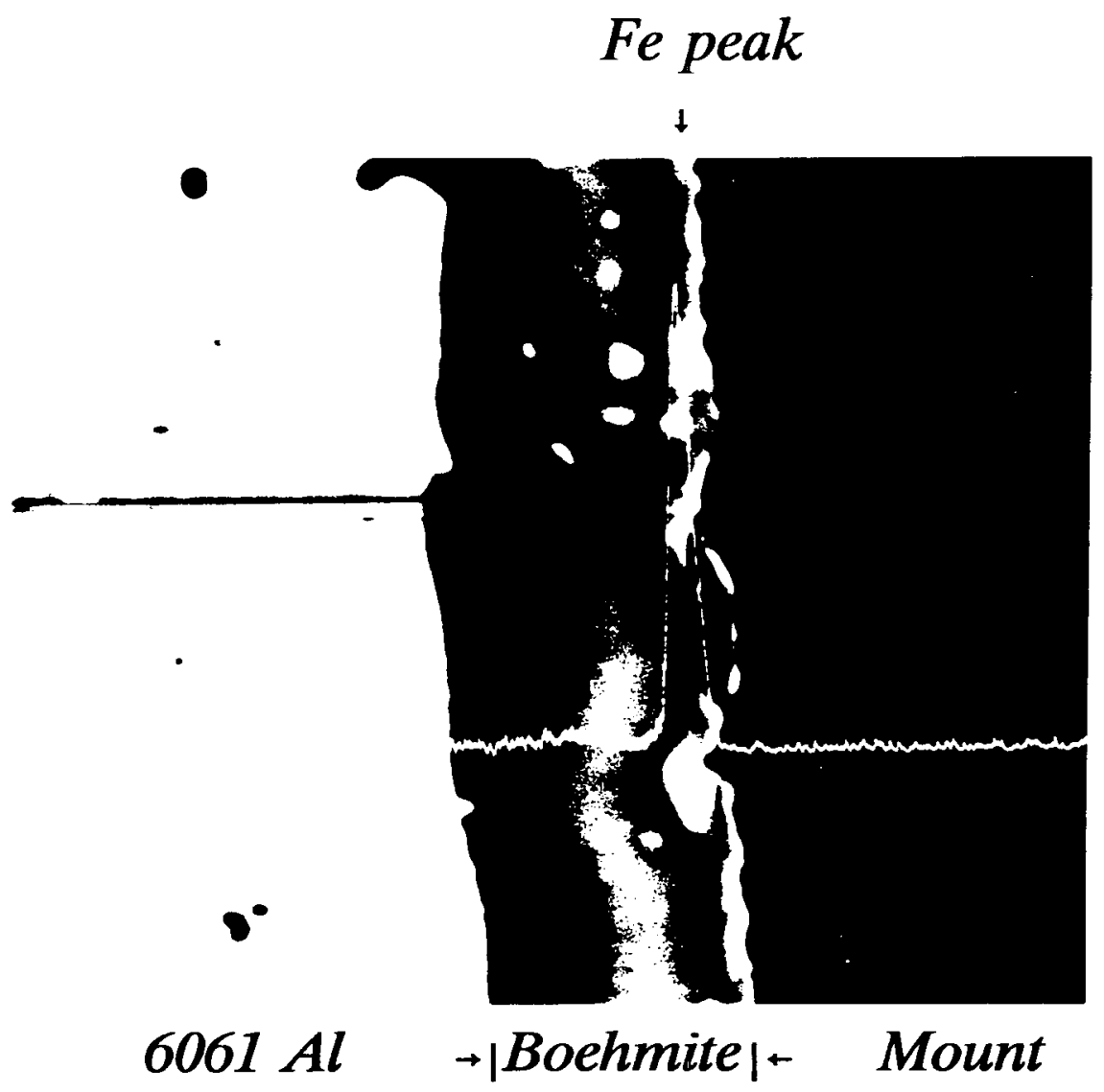

Fig. 5. Electron microprobe scan showing thin layer of iron-rich material on outer surface of film. 


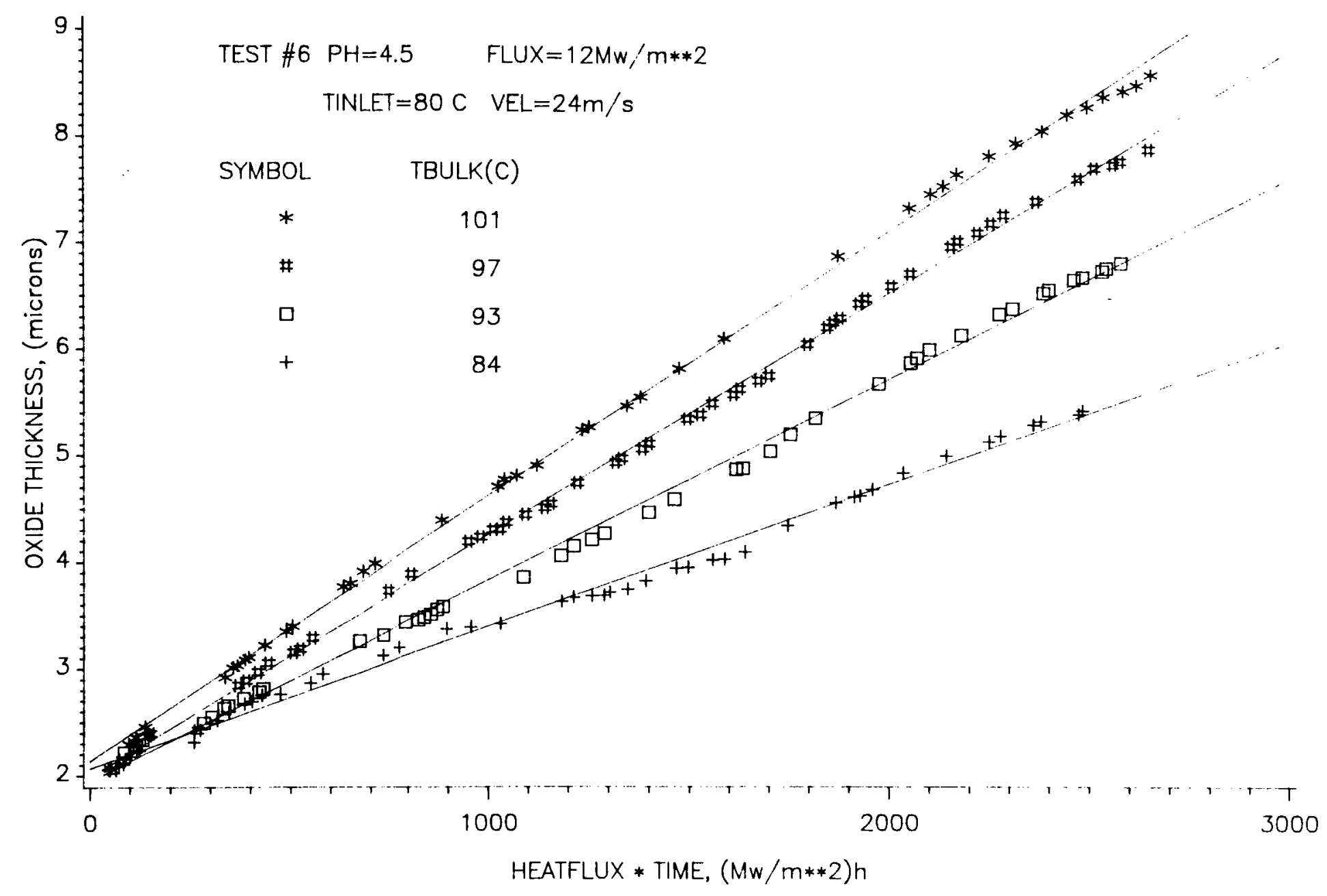

JAC-26MAR90

Fig. 6. Thickness-vs-time results for a $\mathrm{pH} 4.5$ and medium heat flux run. 


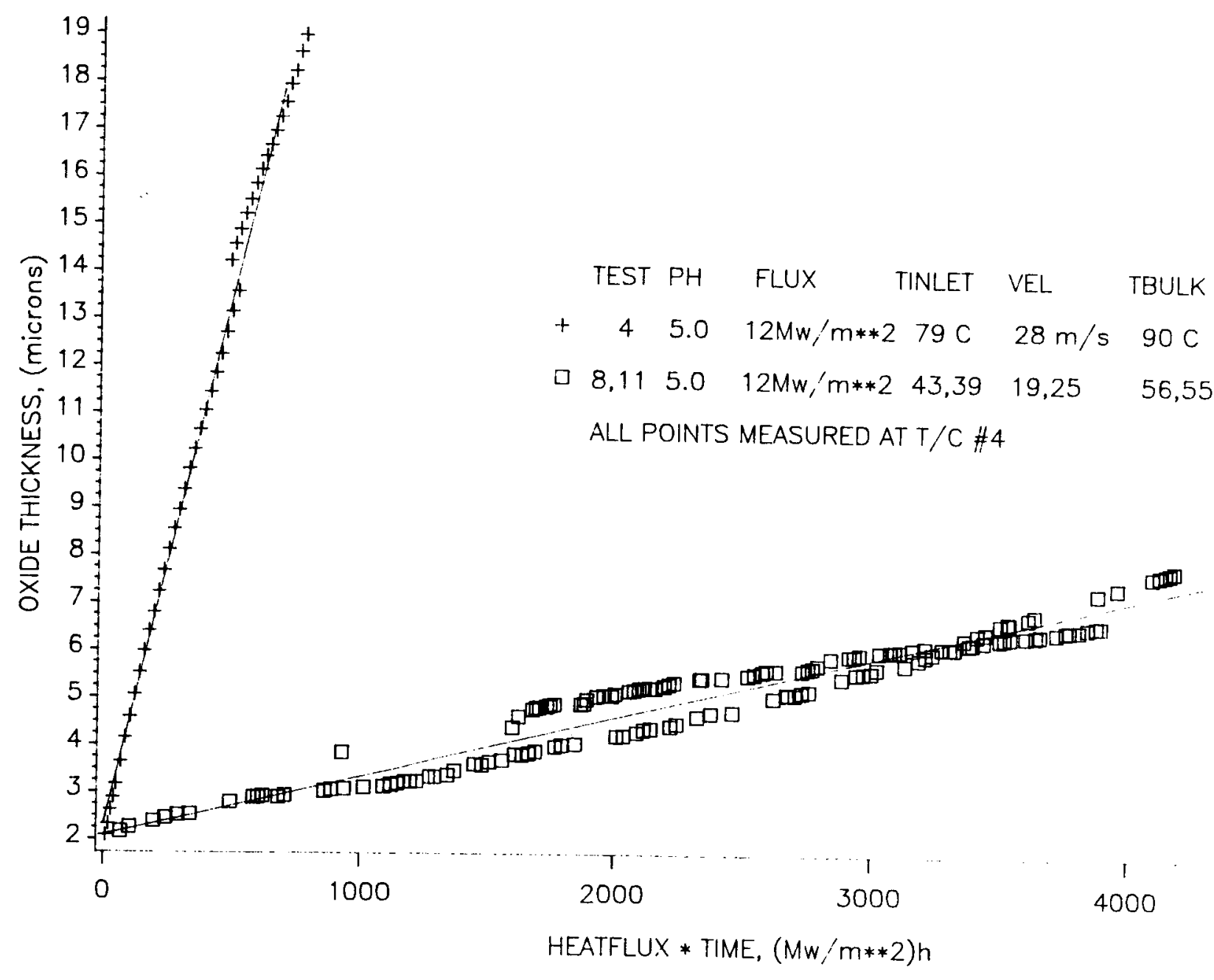

JAC-26MAR90

Fig. 7. Thickness-vs-time results for two different inlet temperature values. 


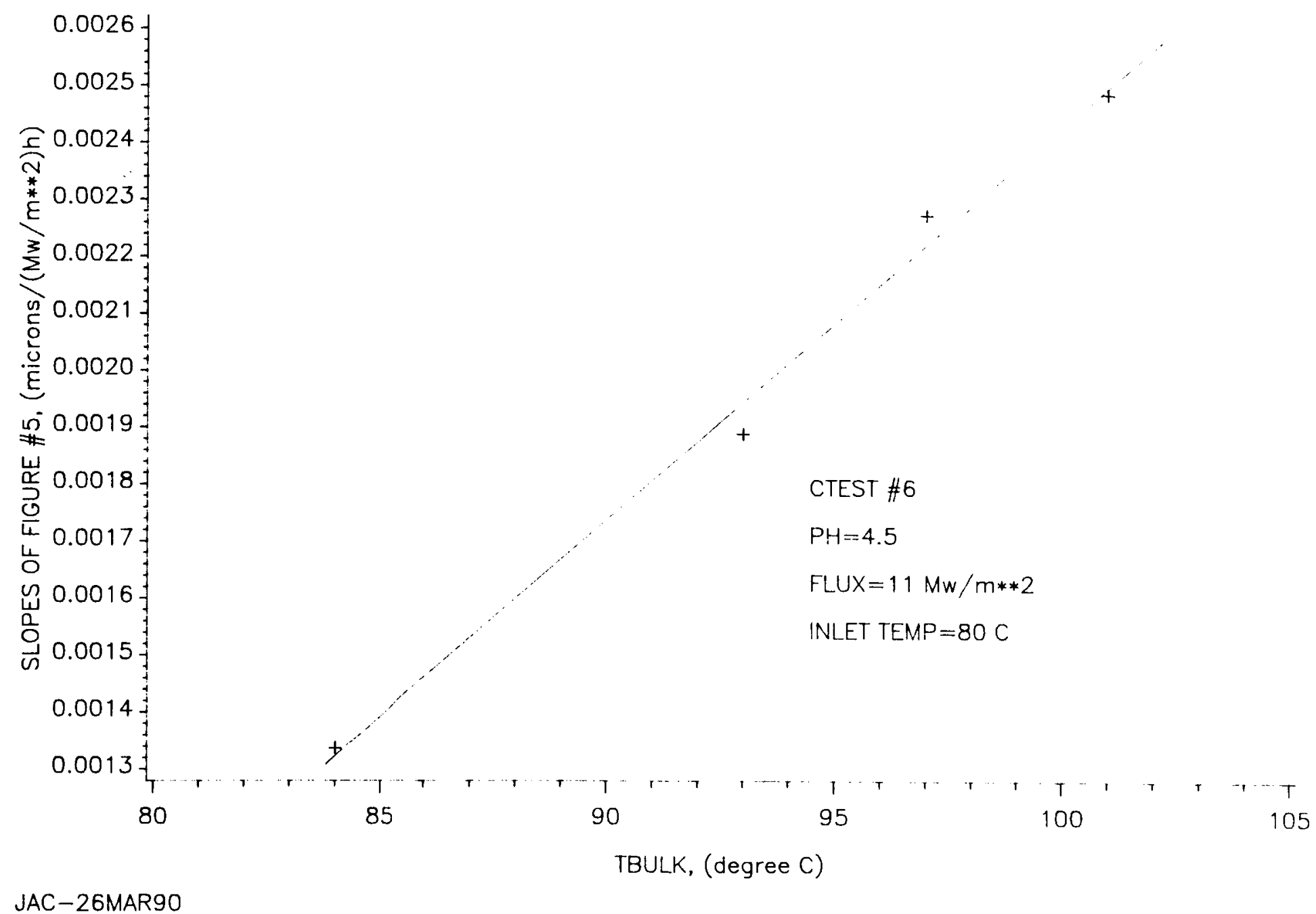

Fig. 8. Oxide growth rate vs bulk water temperature for CTEST 6. 


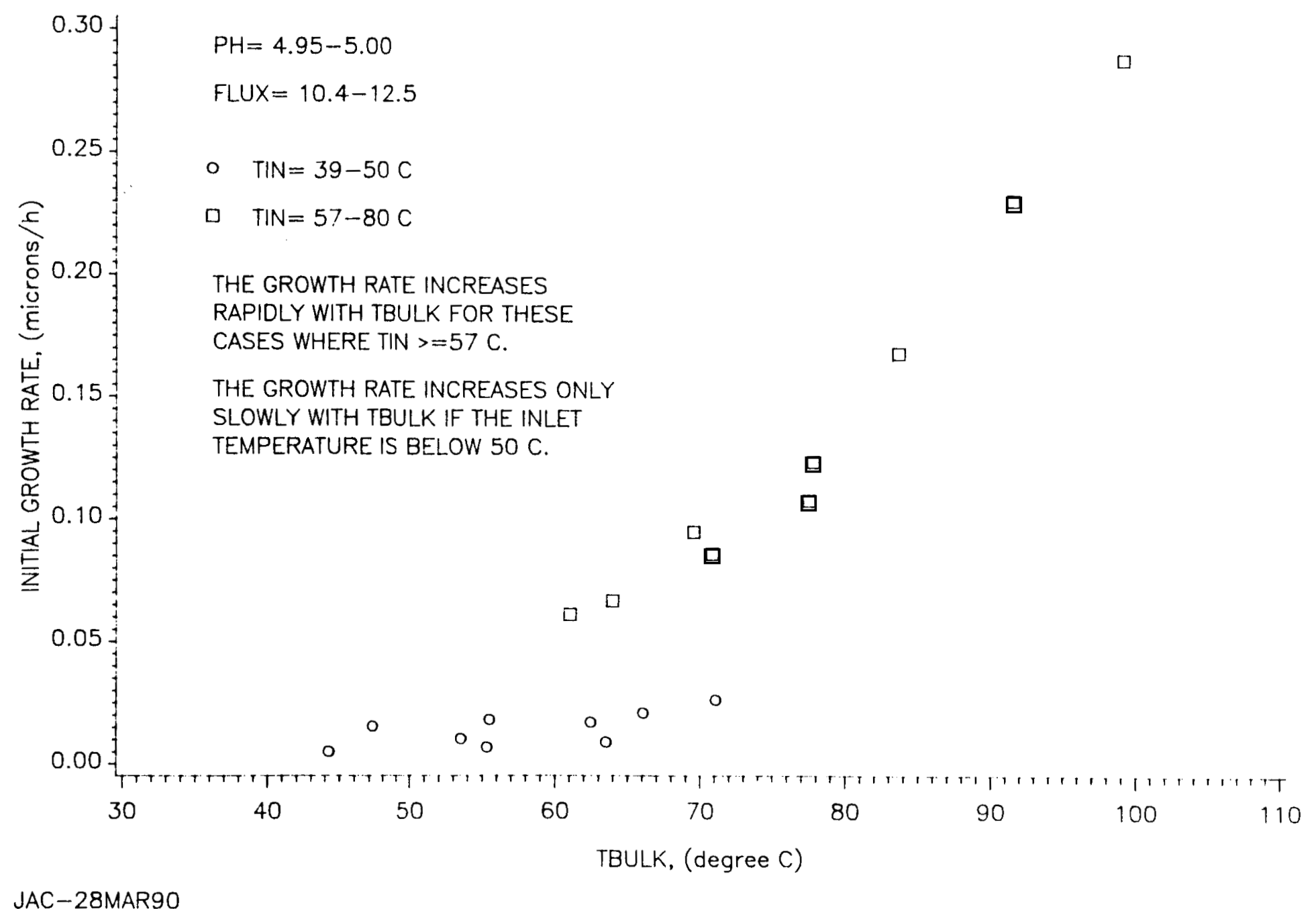

Fig. 9. Initial growth rate vs bulk water temperature for varying inlet temperatures. 
Y213951
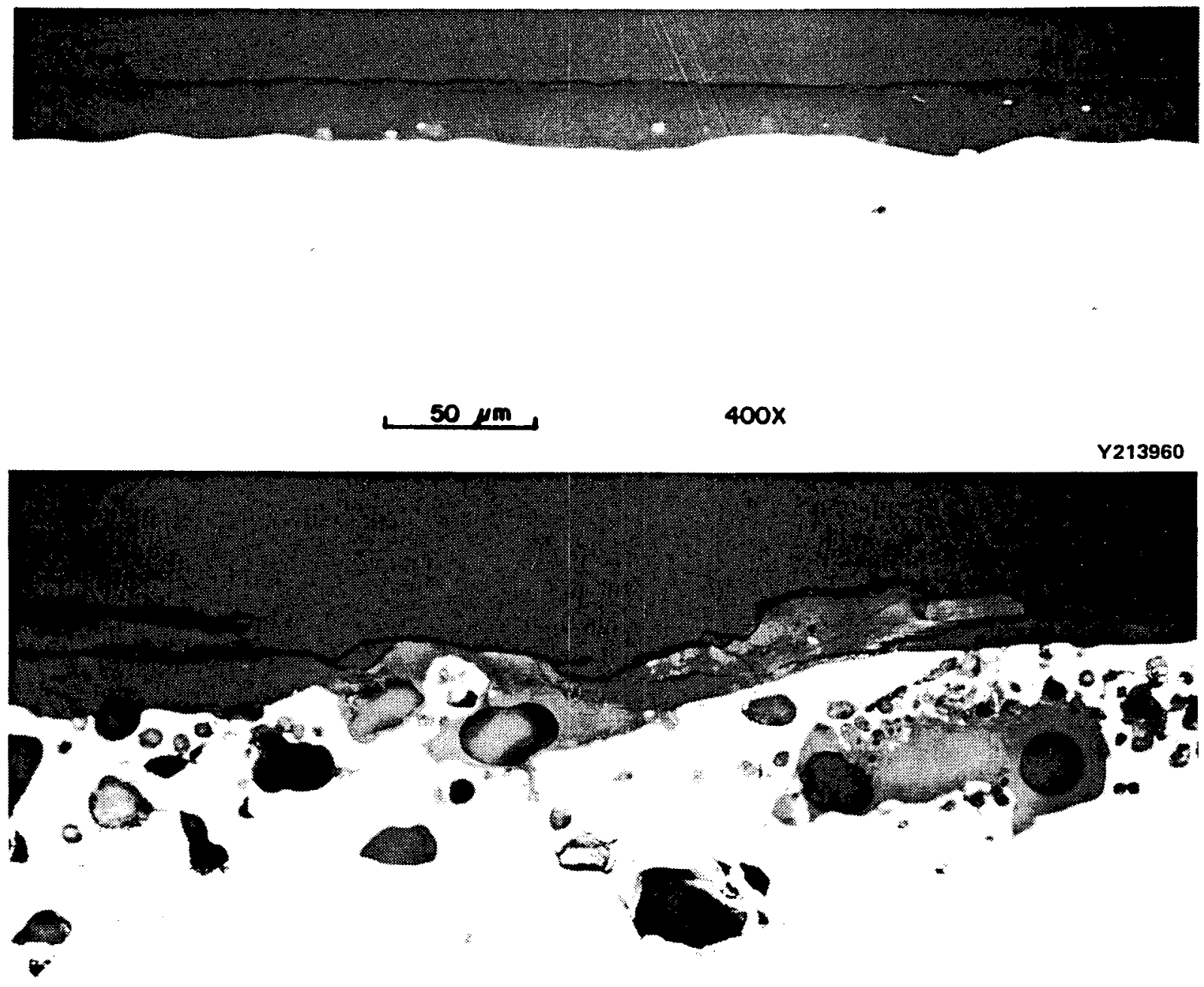

$50 \mathrm{\mu m}, 400 x$

Fig. 10. Cross section of spalled and unspalled regions of test specimen. 
ANS CORROSION TEST 16

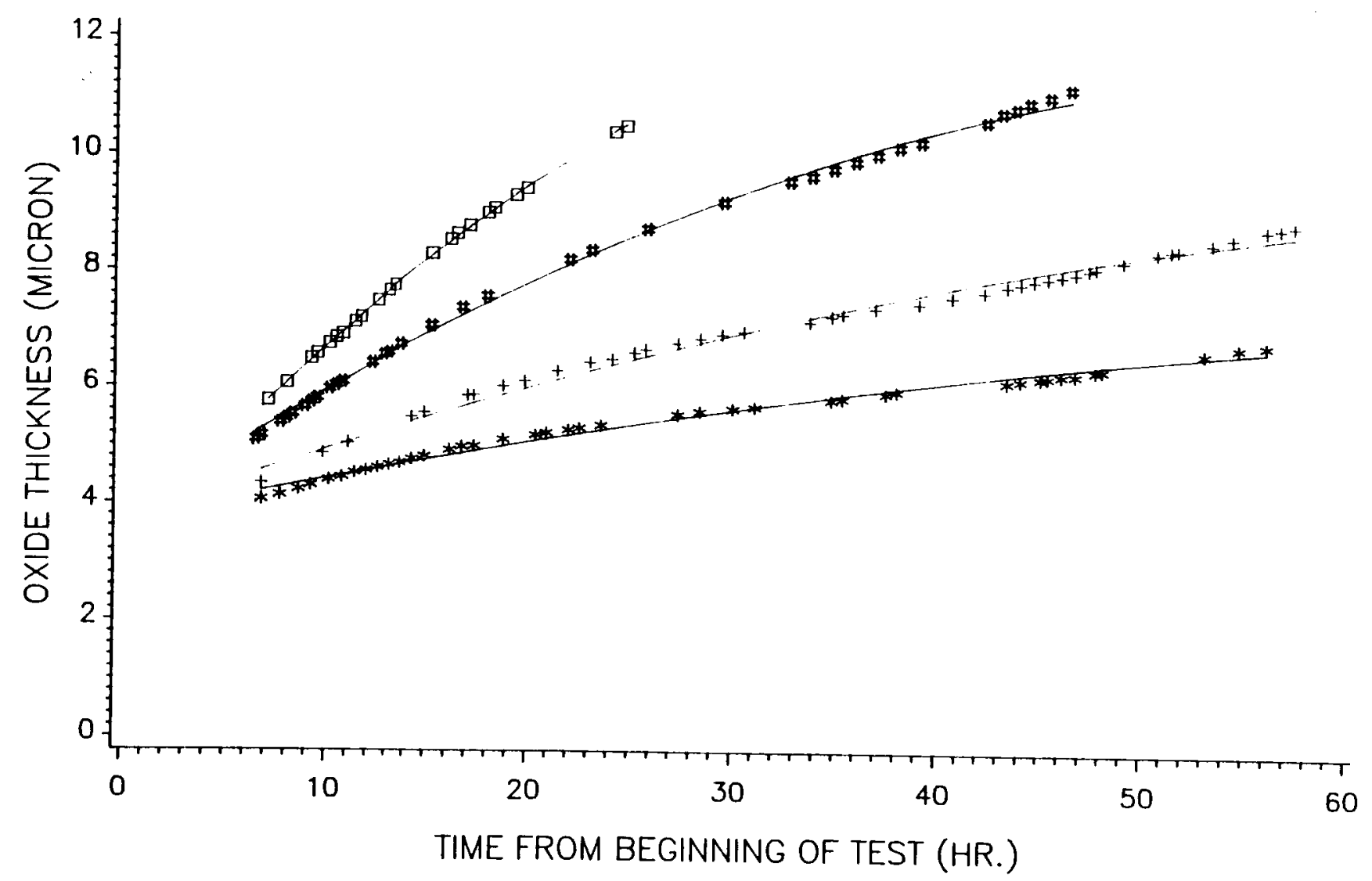

Fig. 11. Oxide growth curves from ANSDAT illustrating use of second-order polynomials to represent data. 


\section{PRED $=A * F L U X * B * T H O X * * C * E X P(D / T M E T A L)$}

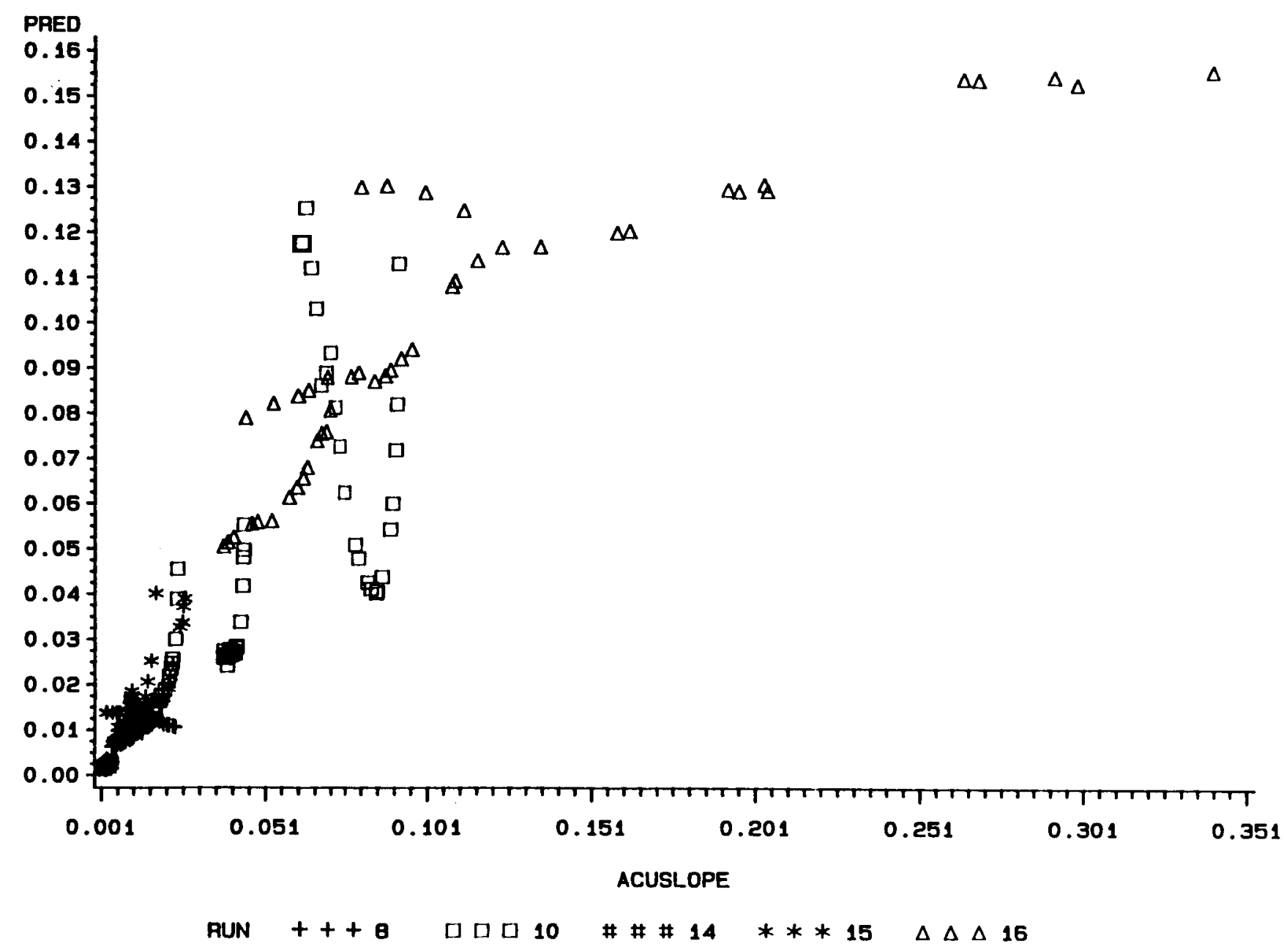

Fig. 12. Measured-vs-predicted growth rates [via Eq. (6)] for CTESTs 8, 10, 14, 15, \& 16. 


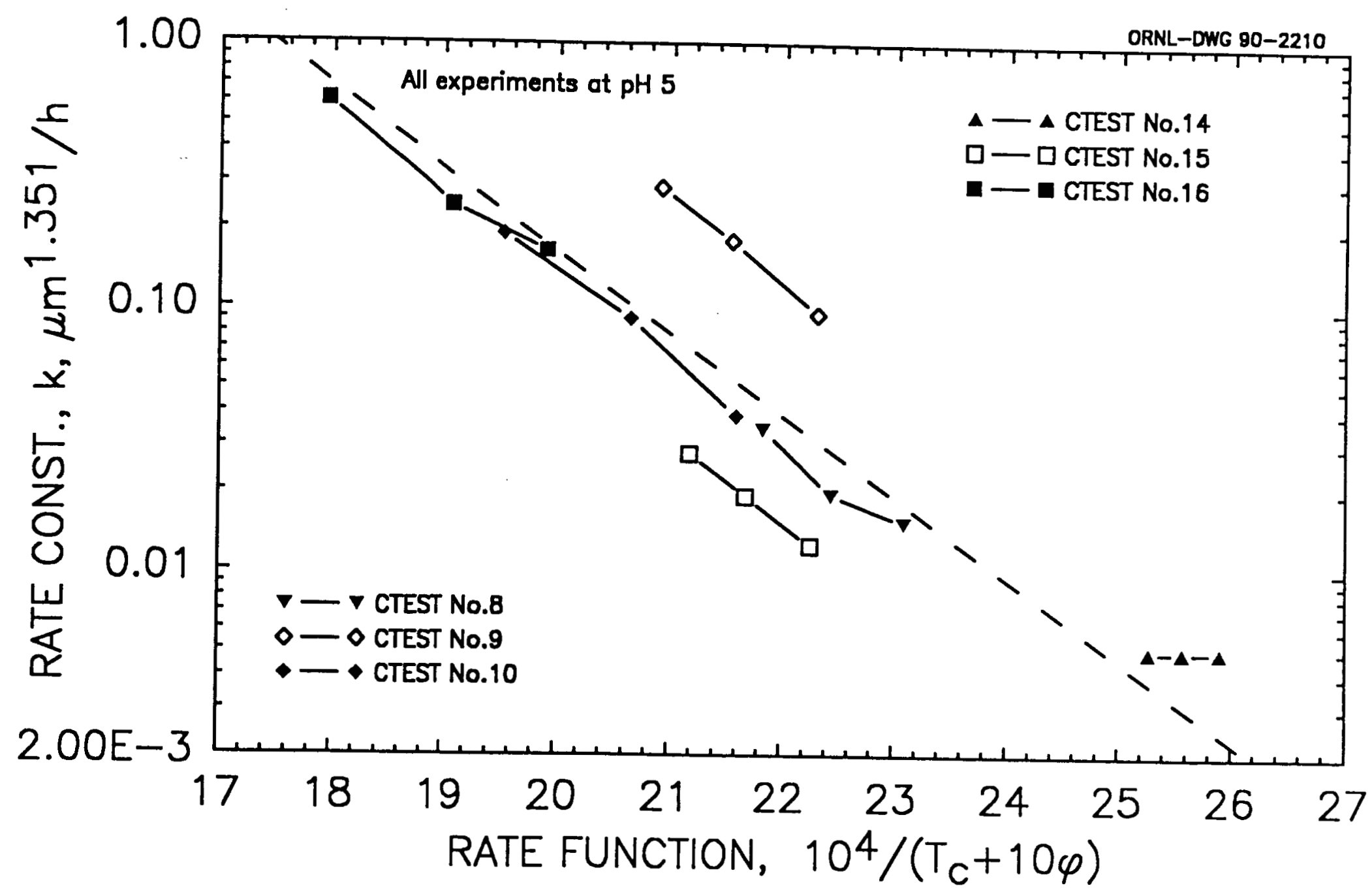
Fig. 13. Arrhenius plot for rate constant $k$ and rate parameter $\left(T_{c}+10 \phi\right)$ showing the
conservative estimator. 


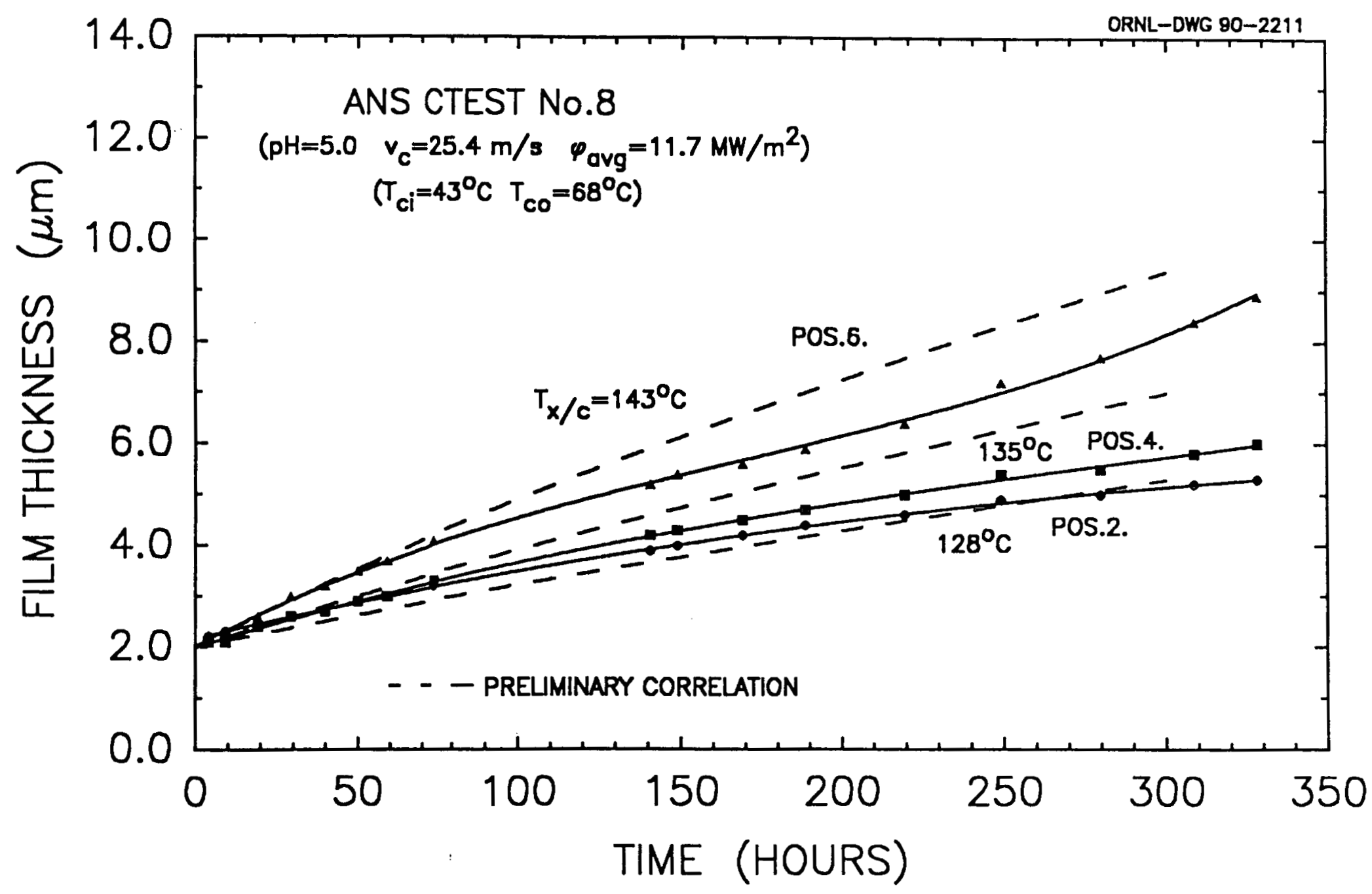

Fig. 14. Measured and predicted film thicknesses for CTEST 8. 


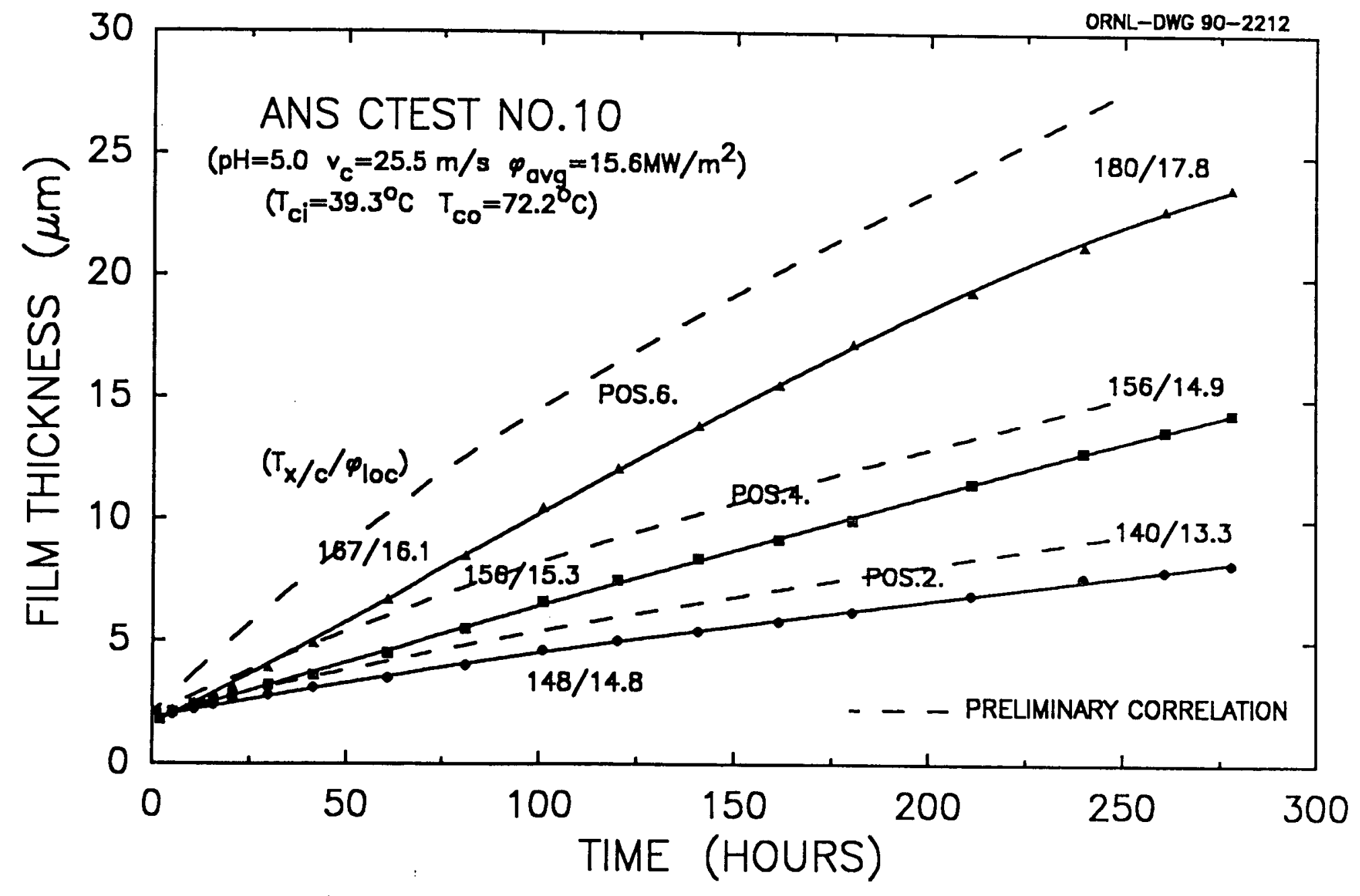

Fig. 15. Measured and predicted film thicknesses for CTEST 10. 


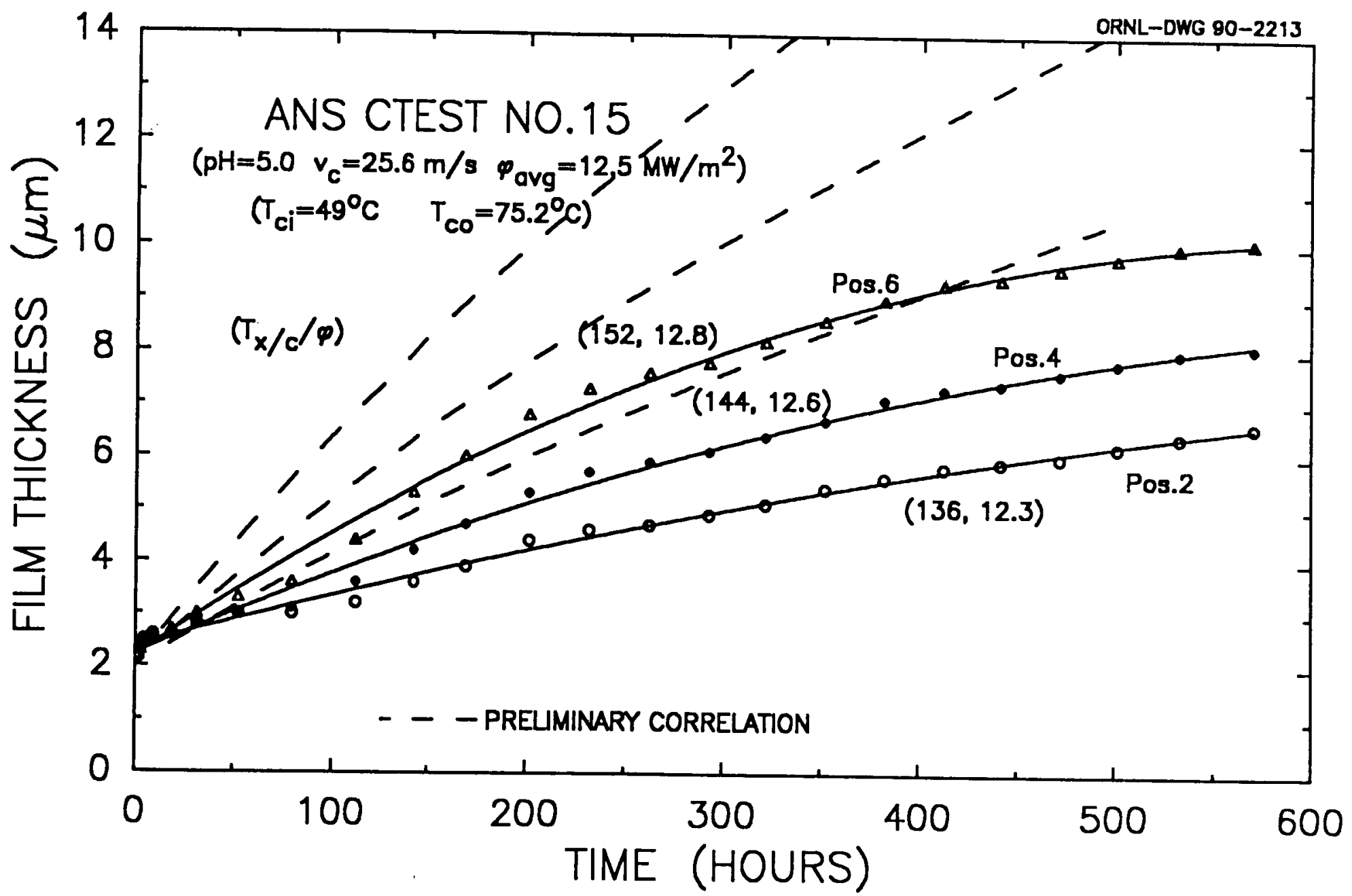

Fig. 16. Measured and predicted film thicknesses for CTEST 15. 


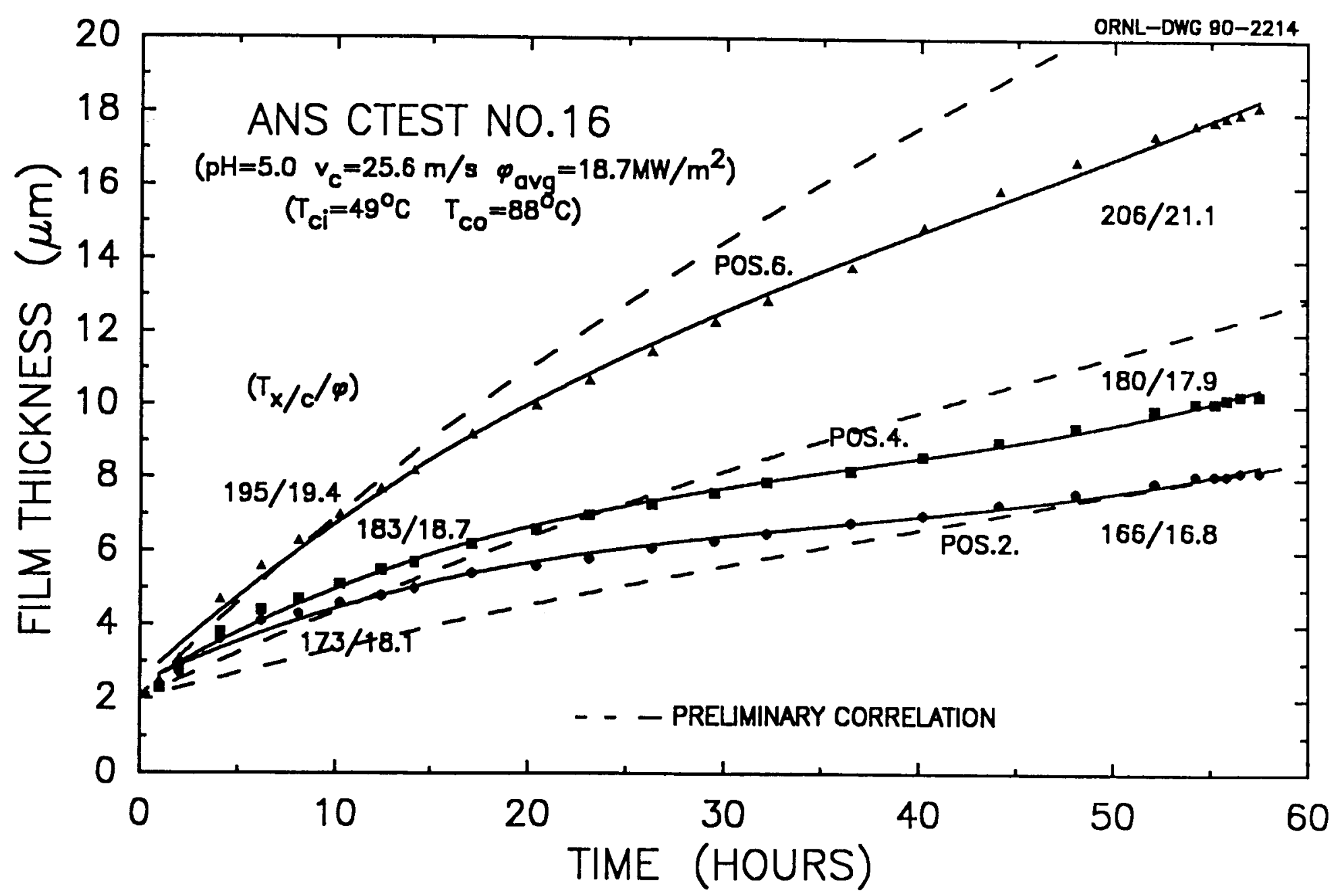

Fig. 17. Measured and predicted film thicknesses for CTEST 16. 


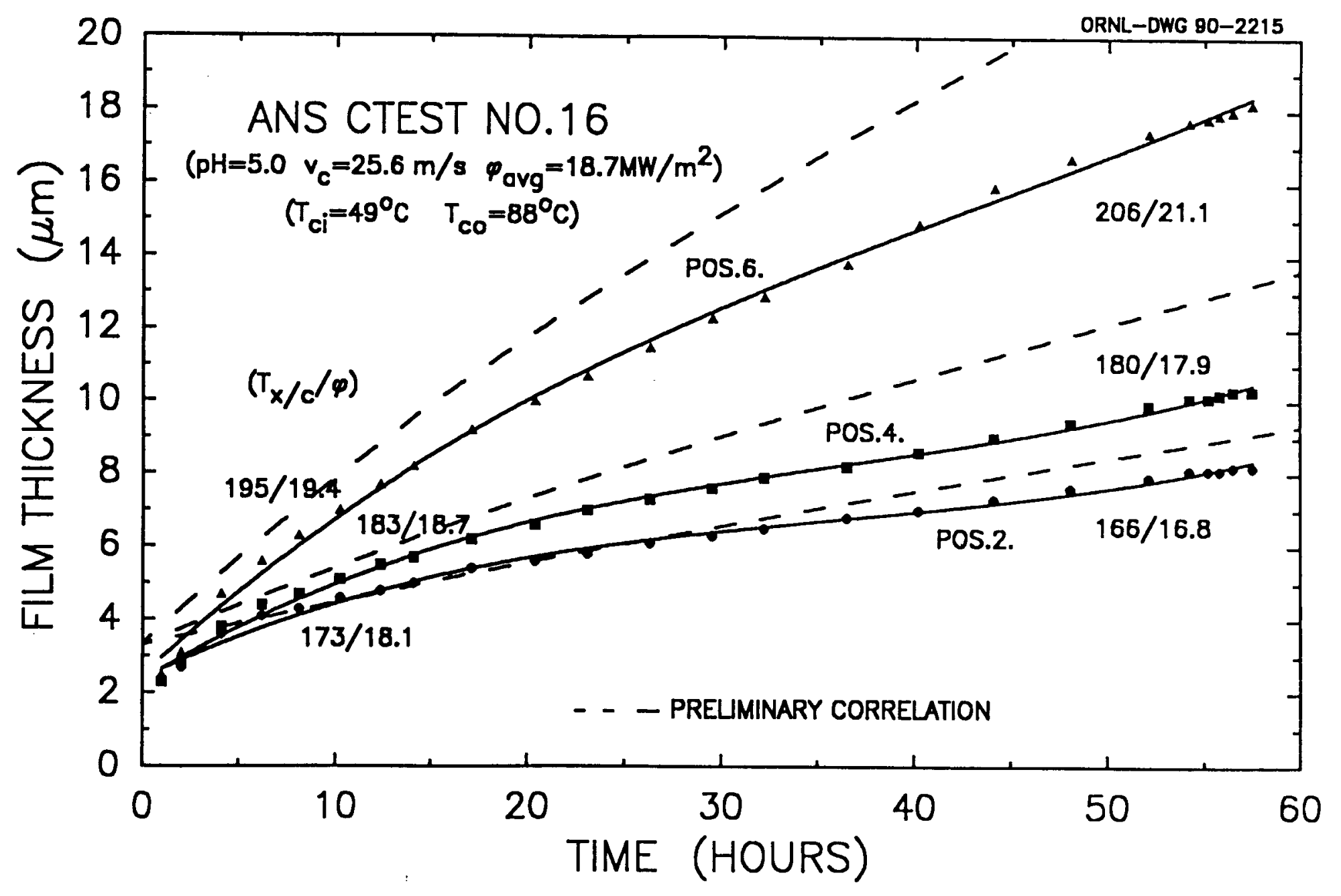

Fig. 18. Measured and predicted film thicknesses for CTEST 16, based on $x_{o}=3.3 \mu \mathrm{m}$. 


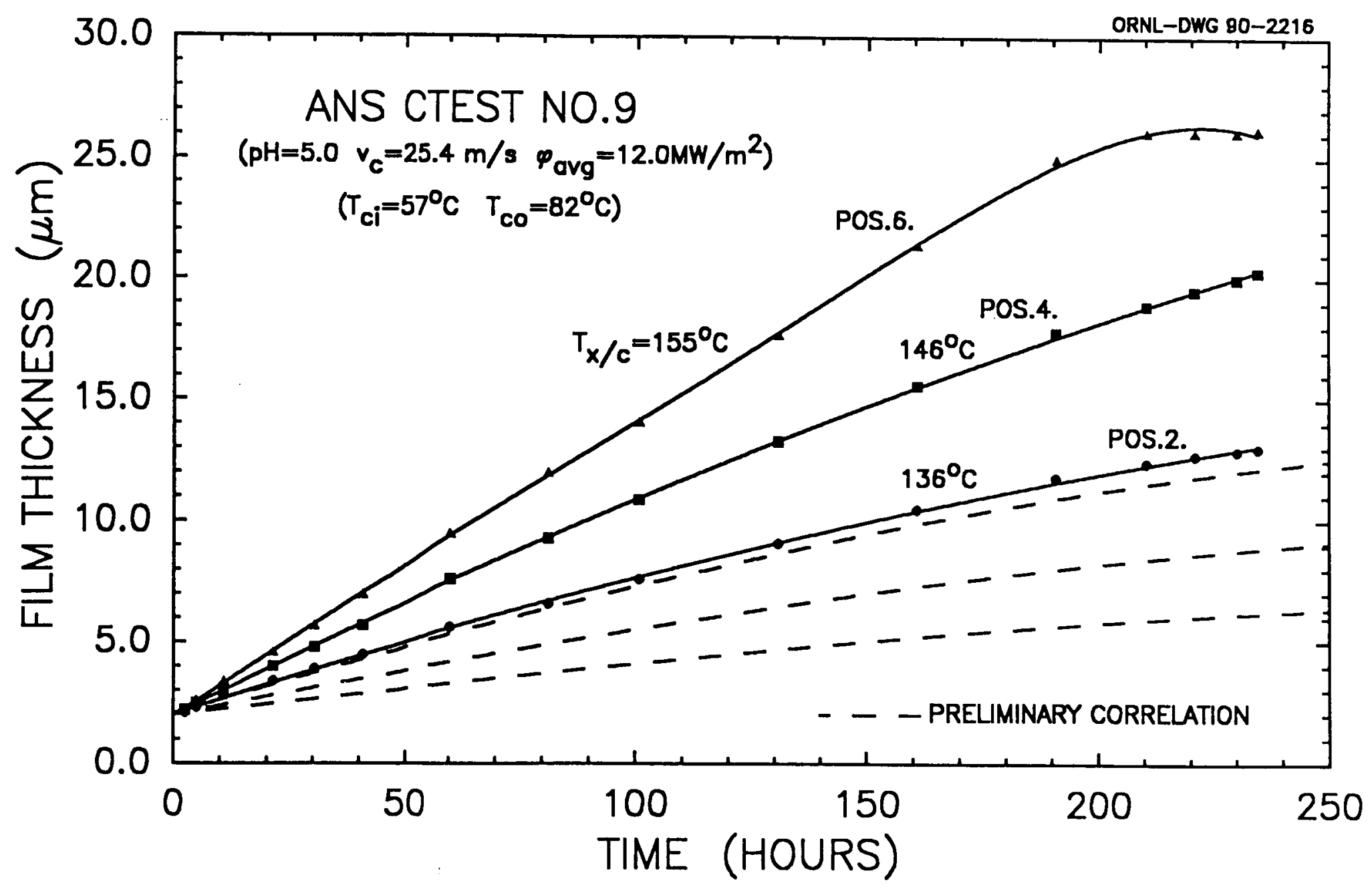

Fig. 19. Measured and predicted film thicknesses for CTEST 9 , a test conducted with $T_{d}=$ $57^{\circ} \mathrm{C}$, out of range intended for preliminary correlation. 


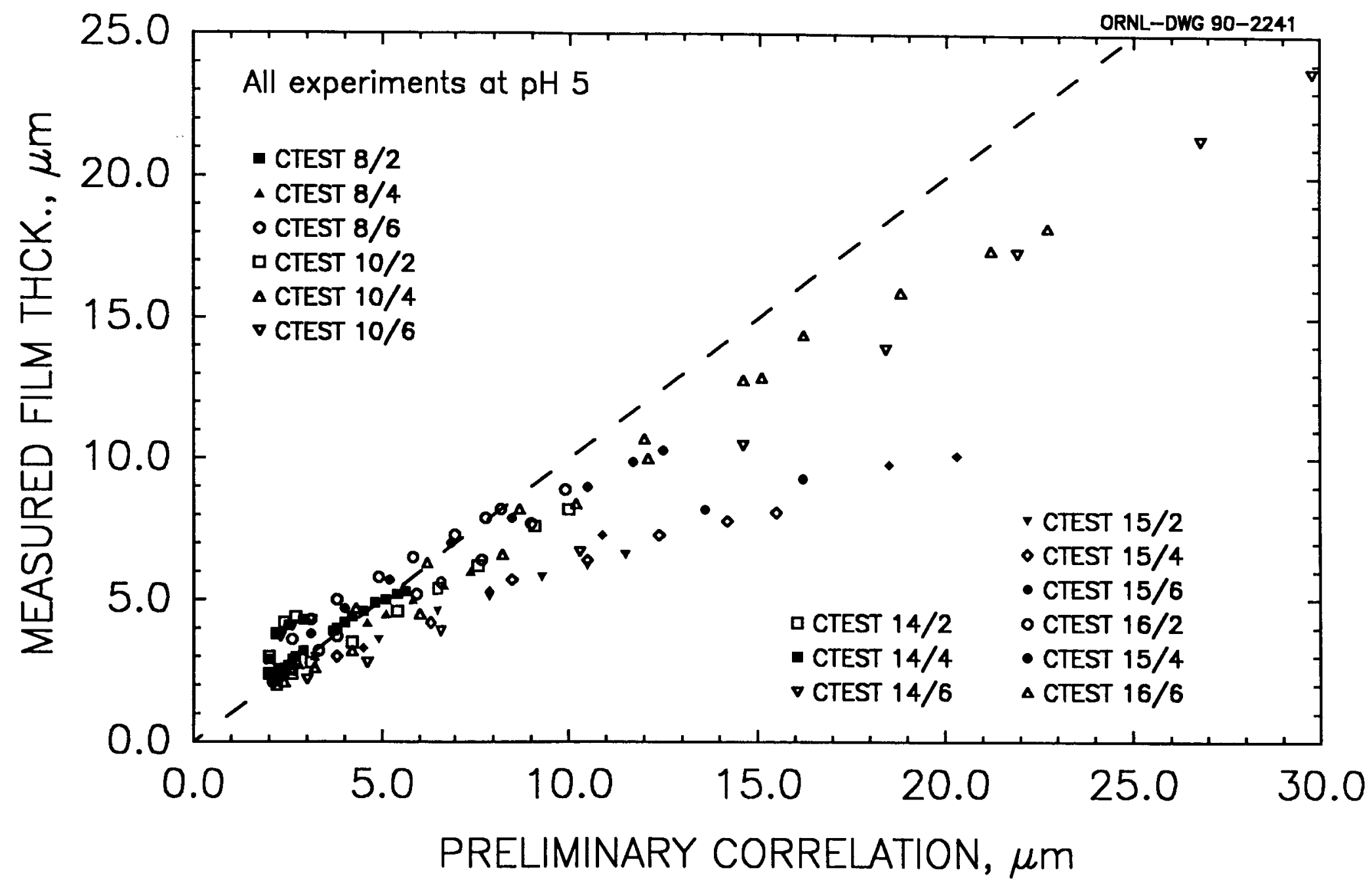

Fig. 20. Measured and predicted film thicknesses according to the preliminary correlation. 


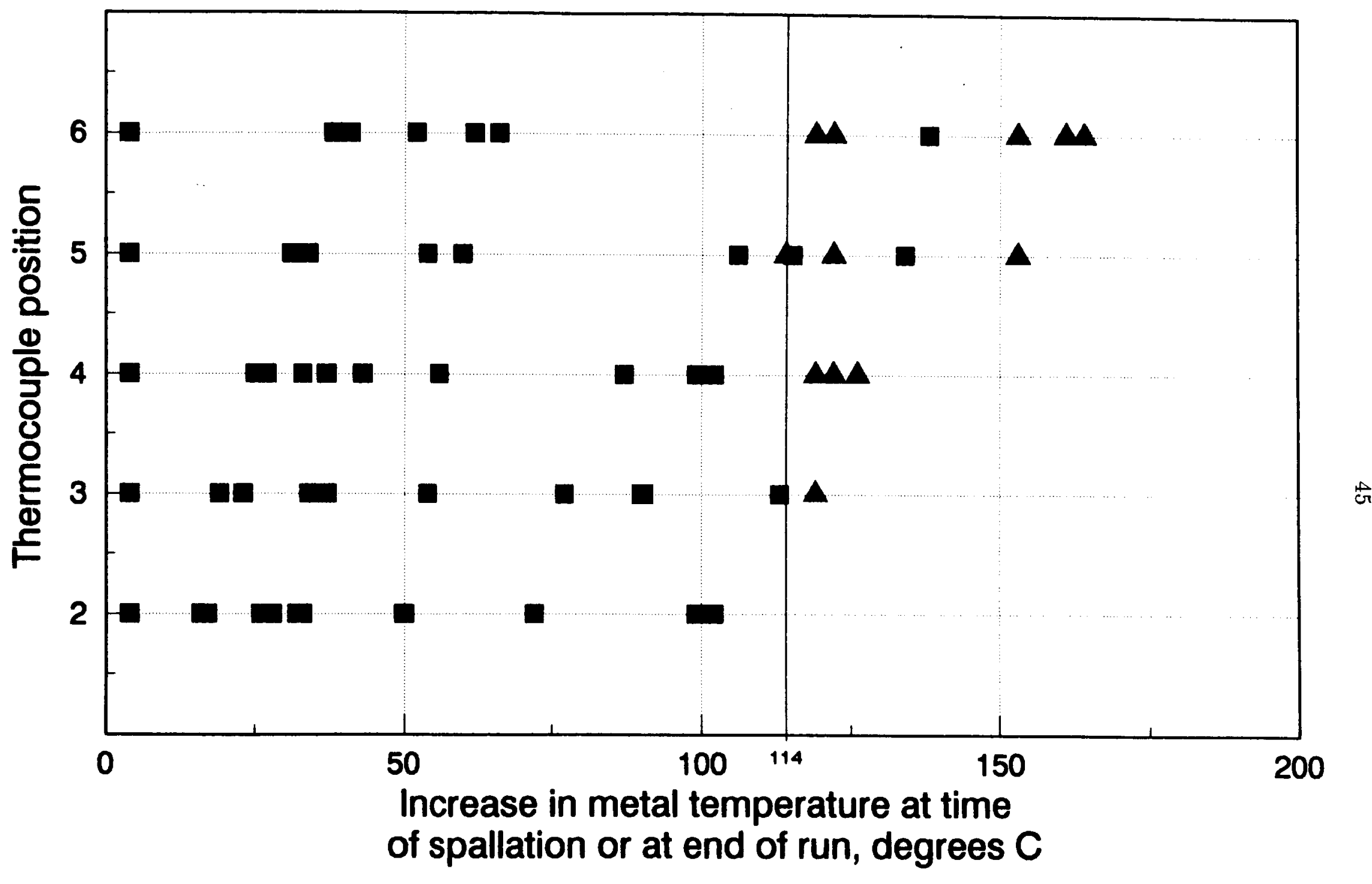

DELTMET2:JAN

\ Did spall Did not spall

Fig. 21. Metal-oxide interface temperatures at time of spallation or at end of run. 


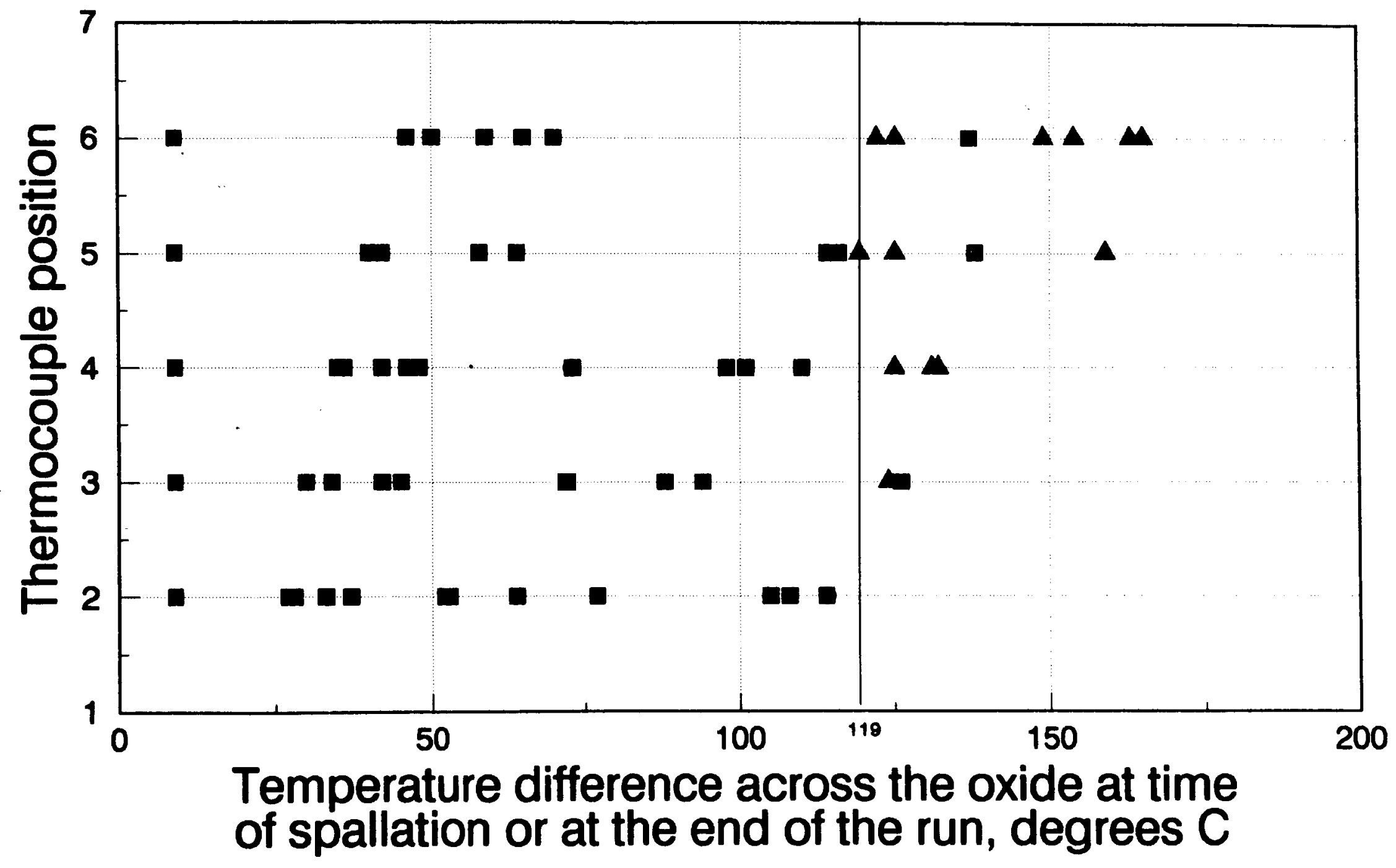

Fig. 22. Temperature difference across the oxide at time of spallation or at end of run. 
ORNL/TM-11517

\section{Internal Distribution}

1. C. W. Alexander

2. R. G. Alsmiller

3. J. L. Anderson

4. B. R. Appleton

5. V. B. Baylor

6. E. E. Bloom

7. R. A. Brown

8. J. R. Buchanan

9. S. H. Buechler

10. N. C. J. Chen

11. G. L. Copeland

12. B. L. Corbett

13. F. C. Difilippo

14. J. R. Distefano

15. J. R. Dixon

16. F. F. Dyer

17. S. R. Ervin

18. K. Ferrell

19. R. E. Fenstermaker

20. G. F. Flanagan

21. W. R. Gambill

22. R. K. Genung

23. M. L. Gildner

24. H. A. Glovier

25. R. M. Harrington

26. J. B. Hayter

27. D. R. Hicks

28. R. W. Hobbs

29. D. T. Ingersoll

30. J. A. Johnson

31. L. M. Jordan

32. H. T. Kerr

33. R. W. Knight

34. R. A. Lillie

35. J. A. March-Leuba
36. B. S. Maxon

37. M. R. McBee

38. T. J. McManamy

39. G. R. McNutt

40-44. B. H. Montgomery

45. R. M. Moon

46. R. K. Nanstad

47-51. R. E. Pawel

52. F. J. Peretz

53. R. T. Primm, III

54. C. C. Queen, Jr.

55. S. Raman

56. J. S. Rayside

57. A. E. Ruggles

58. T. L. Ryan

59. D. L. Selby

60. T. E. Shannon

61. H. B. Shapira

62. G. M. Slaughter

63. R. P. Taleyarkhan

64. P. B. Thompson

65. K. R. Thoms

66. D. B. Trauger

67. C. D. West

68. J. Westbrook

69. M. K. Wilkinson

70. B. A. Worley

71. G. T. Yahr

72-76. G. L. Yoder

77. A. Zucker

78. ORNL Patent Office

79. Central Research Library

80. Document Reference Section

81-82. Laboratory Records Department

83. Laboratory Records (RC)

\section{External Distribution}

84. Alexander Adams, U.S. Nuclear Regulatory Commission, MS-10-0-21, Washington, DC 20555

85. Jurgen Ahlf, Joint Research Center, Institute for Advanced Materials, $1755 \mathrm{ZG}$ Petten, P. O. Box 2, The Netherlands 
86. Dick Ambrosek, Idaho National Engineering Laboratory, P. O. Box 1625, Idaho Falls, ID 83415-3420

87. Ed Anderson, EG\&G Idaho, Inc., P. O. Box 1625, Idaho Falls, ID 83415-7114

88. William Anderson, Babcock \& Wilcox, Mt. Athens Road, P. O. Box 785, Lynchburg, VA 24505

89. Peter Armbruster, Institut Laue-Langevin, 156X, 38042 Grenoble Cedex, France

90. Steve Atkinson, Idaho National Engineering Laboratory, P. O. Box 1625, Idaho Falls, ID 83415-7121

91. John Axe, Brookhaven National Laboratory, Building 510A, Upton, NY 19973

92. Anton Axmann, Hahn-Meitner Institute Berlin, N3, Glienicker Str. 100, D-1000 Berlin 39, Federal Republic of Germany

93. Lewis J. Baker, Materials Physics \& Metallurgy Division, Building 521.11, Harwell Laboratory, Oxfordshire OX11 ORA, United Kingdom

94. Bob Bari, Brookhaven National Laboratory, Department of Nuclear Energy, Building 197C, Upton, NY 11973

95. Dr. Ekkehardt Bauer, Institut Laue-Langevin, 156X 38042 Grenoble Cedex, France

96. J. M. Baugnet, Nuclear Services Program, S.C.K./C.E.N., Boeretang 200, B2400 Mol, Belgium

97. R. N. Beatty, Idaho National Engineering Laboratory, P. O. Box 1625, Idaho Falls, ID 83415-7129

98. Dr. Klaus Böning, Fakultät für Physik E21, Technische Universität München, D-8046 Garching, Federal Republic of Germany

99. Paul Breant, CEN Saclay, SPS ORPHEE, 91191 Gif-sur-Yvette Cedex, France

100. Mel Buckner, Savannah River Laboratory, Aiken, SC 29808

101. H. A. Capote, Burns \& Roe, 800 Kinderkamack Road, Oradell, NJ 07649

102. Lap Cheng, Brookhaven National Laboratory, Department of Nuclear Energy, Building 197C, Upton, NY 11973

103. Kurt N. Clausen, RISO National Laboratory, Physics Department Postbox 49, DK-4000 Roskilde, Denmark

104. M. F. Collins, Nuclear Reactor, McMaster University, Hamilton, Ontario, L8S, 4K1, Canada

105. C. Desandre, Technicatome, Centre d'Etudes Nucleaires de Saclay, BP17, 92291 Gif/Yvette Cedex, France

106. James DeVine, Battelle Northwest Laboratory, Mail Stop P837, P. O. Box 999, Richland, Washington 99352

107. Robert Dillon, 623 Cottonwood, Richland, WA 99352

108. A. F. DiMeglio, Rhode Island Atomic Energy Commission, Rhode Island Nuclear Science Center, South Ferry Road, Narragansett, RI 02882

109. B. Farnoux, CEN Saclay, Laboratoire Leon Brillouin, 91191 Gif/Yvette Cedex, France

110. G. N. Fillmore, Idaho National Engineering Laboratory, P. O. Box 1625, Idaho Falls, ID $83415-3420$

111. Dr. B. Chalmers Frazer, Materials Science Division, Office of Basic Energy Sciences, Office of Energy Research, U.S. Department of Energy, Germantown, ER-132, Washington, DC 20545

112. R. R. Fullwood, Building 130, Brookhaven National Laboratory, Upton, NY 11973

113. G. W. Gibson, P. O. Box 923, Hailey, ID 83333

114. M. L. Griebenow, Idaho National Engineering Laboratory, P. O. Box 1625, Idaho Falls, ID 83415-3519

115. J. C. Griess, Jr., 10803 Fox Park Road, Knoxville, TN 37931 
116. G. H. Hanson, 444 Seventh St., Idaho Falls, ID 83401

117. Otto K. Harling, Massachusetts Institute of Technology, 77 Massachusetts Avenue, Cambridge, MA 02139

118. Masatoshi Hayashi, Research Reactor Institute, Kyoto University, Kumatori-cho, Sennan-gun, Osaka 590-04, Japan

119. R. R. Hobbins, Idaho National Engineering Laboratory, P. O. Box 1625, Idaho Falls, ID $83415-2506$

120. Dr. Hugh S. Isaacs, Bldg 480, Brookhaven National Laboratory, Upton, Long Island, NY 11973

121. R. D. Johnson, Idaho National Engineering Laboratory, P. O. Box 1625, Idaho Falls, ID $83415-7106$

122. Walt L. Kirshner, Los Alamos National Laboratory, Mail Stop K-575, P. O. Box 1663, Los Alamos, NM 87545

123. Wilfried Krull, GKSS, Postfach 1160, D-2054 Geesthacht, Federal Republic of Germany

124. J. A. Lake, Manager, Nuclear Engineering and Reactor Design, Idaho National Engineering Laboratory, P. O. Box 1625, Idaho Falls, ID 83415

125. Albert G. Lee, Atomic Energy of Canada, Ltd., Whiteshell Nuclear Research Establishment, Pinawa, Manitoba, R0E 1L0, Canada

126. Charles Lewis, Babcock \& Wilcox, P. O. Box 785, Lynchburg, VA 24505-0785

127. Mr. Robert F. Lidstone, Atomic Energy of Canada, Ltd., Whiteshell Nuclear Research Establishment, Pinawa, Manitoba, R0E 1L0, Canada

128. John Marks, Research and Test Reactor Fuel Elements, Babcock and Wilcox Co., P. O. Box 785, Lynchburg, VA 24505

129. Shajiro Matsuura, Japan Atomic Energy Research Institute, Tokai Research Establishment, Tokai-mura, Naka-gun, Ibaraki-ken, Japan

130. M. H. McBride, Oak Ridge Operations, U.S. Department of Energy, Building 7900, MS-6387, P. O. Box 2008, Oak Ridge, TN 37831-6387

131. J. Charles McKibben, Research Reactor Facility, University of Missouri-Columbia, Research Park, Columbia, MO 65211

132. E. McVey, Chalk River Nuclear Laboratories Sta 61, Atomic Energy of Canada, Ltd, Chalk River, Ontario, Canada KOJ 1JO

133. Ross Miller, Atomic Energy of Canada, Ltd., Research Company, Chalk River Nuclear Laboratories, Chalk River, Ontario, K0J 1J0, Canada

134. Hirokatsu Nakata, Project Engineering Division, Department of JMTR Project, Japan Atomic Energy Research Institute, Oarai Ibaraki-ken, Japan

135. Robert J. Neuhold, U.S. Department of Energy, Germantown, NE-472, Washington, DC 20545

136. Les C. Oakes, Electric Power Research Institute (EPRI), Building 2, Room 252, P. O. Box 10412, Palo Alto, CA 94303

137. C. Oh, Idaho National Engineering Laboratory, P. O. Box 1625, Idaho Falls, ID 83415-2210

138. R. S. Ondrejcin, E. I. duPont de Nemours \& Co., Savannah River Laboratory, Aiken, SC 29808

139. Stephen L. Ostrow, Ebasco Services, Inc., 2 World Trade Center, 89th Floor, New York, NY 10048

140. N. E. Pace, Idaho National Engineering Laboratory, EG\&G Idaho, Inc., P. O. Box 1625, Idaho Falls, ID 83415-3515 
141. Dr. Paul Y. Pan, Los Alamos National Laboratory, Mail Stop K559, P. O. Box 1663, Los Alamos, NM 87545

142. Yuri V. Petrov, Leningrad Nuclear Physics Institute, Academy of Science of USSR, 188350 Gatchina, Leningrad District, USSR

143. Henry J. Prask, National Institute for Standards \& Technology, A-106 Reactor, Gaithersburg, MD 20899

144. Harry E. Preble, Babcock \& Wilcox, P. O. Box 785, Lynchburg, VA 24505-0785

145. Thomas J. Raney, Ebasco Services, Inc., 2 World Trade Center, 89th Floor, New York, NY 10048

146. Hans-Joachin Roegler, Interatom GmbH, Friedrich-Ebert-Strasse, D-5060 BergischGladbach 1, Federal Republic of Germany

147. Dr. John J. Rush, National Institute of Standards and Technology, Reactor Radiation Division, Building 235, Washington, DC 20234

148. Dr. W. E. Ruther, Argonne National Laboratory, Building 212, 9700 South Cass Avenue, Argonne, IL 60439

149. John M. Ryskamp, Idaho National Engineering Laboratory, P. O. Box 1625, Idaho Falls, ID 83415

150. D. W. Shannon, Battelle Northwest Laboratory, Mail Stop P837, P. O. Box 999, Richland, WA 99352

151. Professor Toshikazu Shibata, Atomic Energy Research Institute, Kinki University, Kowakae, Higashi-Osaka, Osaka 577, Japan

152. Eiji Shirai, Department of Research Reactor Operation, Japan Atomic Energy Research Institute, Tokai-mura, Naka-gun, Ibaraki-ken 319-11, Japan

153. J. B. Slater, Atomic Energy of Canada, Limited., Research Company, Chalk River Nuclear Laboratories, Chalk River, Ontario, K0J 1J0, Canada

154. Roland Smith, Argonne National Laboratory, P. O. Box 2528, Idaho Falls, ID 83403

155. J. L. Snelgrove, Coordinator, Engineering Applications, RERTR Program, Argonne National Laboratory, 9700 South Cass Avenue, Argonne, IL 60439

156. J. D. Spencer, Savannah River Laboratory, Aiken, SC 29808

157. Dr. Robert Tapping, Chalk River Nuclear Laboratories, Sta 61, ATomic Energy of Canada, Limited, Chalk River, Ontario, Canada KOJ 1JO

158. Crispin W. Thiessen, Vice President/Manager, Savannah River Laboratory, Aiken, SC 29808

159. Dr. Iran L. Thomas, Director, Materials Science Division, Office of Energy Research, U.S. Department of Energy, Germantown ER-13, Washington, DC 20545

160. Masahiko Utsuro, Research Reactor Institute, Kyoto University, Kumatori-cho, Sennan-gun, Osaka, Japan

161. Jacques Verdier, Centre d'Etudes Nucleaires, SBT, 85X, 38041 Grenoble Cedex, France

162. K. Vinjamuri, Idaho National Engineering Laboratory, P. O. Box 1625, Idaho Falls, ID 83415-2506

163. R. P. Wadkins, Idaho National Engineering Laboratory, P. O. Box 1625, Idaho Falls, ID 84515

164. James M. Warren, Gilbert Commonwealth, 320 Cedar Bluff Road, Suite 300 , Knoxville, TN 37923

165. John Weeks, Brookhaven National Laboratory, Associated Universities, Inc., Building 130, Upton, NY 11973

166. R. F. Wichman, Atomic Energy of Canada Limited., Research Company, Chalk River Nuclear Laboratories, Chalk River, Ontario, K0J 1J0, Canada 
167. D. K. Wilfert, Energy Programs, U.S. Department of Energy, Oak Ridge Operations, Building 7900, MS-6387, P. O. Box 2008, Oak Ridge, TN 37831-6387

168. R. J. Willard, U.S. Department of Energy, Oak Ridge Operations, P. O. Box 2001, Oak Ridge, TN 37831-2001

169. Patrick Williams, Babcock \& Wilcox, NNSD, Mail Code 61, P. O. Box 785, Lynchburg, VA 24505

170. Office of Assistant Manager for Energy Research and Development, U.S. Department of Energy, Oak Ridge Operations, P. O. Box 2001, Oak Ridge, TN 37831-2001

171-180. Office of Scientific and Technical Information, P. O. Box 62, Oak Ridge, TN 37831 